\title{
The Pathological Roles of Ganglioside Metabolism in Alzheimer's Disease: Effects of Gangliosides on Neurogenesis
}

\author{
Toshio Ariga, Chandramohan Wakade, and Robert K. Yu \\ Institute of Molecular Medicine and Genetics and Institute of Neuroscience, Medical College of Georgia, \\ 15th street, Augusta, GA 30912, USA \\ Correspondence should be addressed to Robert K. Yu, ryu@mcg.edu
}

Received 20 October 2010; Accepted 8 December 2010

Academic Editor: Katsuhiko Yanagisawa

Copyright (๑) 2011 Toshio Ariga et al. This is an open access article distributed under the Creative Commons Attribution License, which permits unrestricted use, distribution, and reproduction in any medium, provided the original work is properly cited.

Conversion of the soluble, nontoxic amyloid $\beta$-protein $(\mathrm{A} \beta)$ into an aggregated, toxic form rich in $\beta$-sheets is a key step in the onset of Alzheimer's disease (AD). It has been suggested that $\mathrm{A} \beta$ induces changes in neuronal membrane fluidity as a result of its interactions with membrane components such as cholesterol, phospholipids, and gangliosides. Gangliosides are known to bind $\mathrm{A} \beta$. A complex of GM1 and $\mathrm{A} \beta$, termed "GA $\beta$ ", has been identified in AD brains. Abnormal ganglioside metabolism also may occur in AD brains. We have reported an increase of Chol- $1 \alpha$ antigens, GQ1b $\alpha$ and GT1a $\alpha$, in the brain of transgenic mouse AD model. GQ1b $\alpha$ and GT1a $\alpha$ exhibit high affinities to A $\beta$ s. The presence of Chol-1 $\alpha$ gangliosides represents evidence for genesis of cholinergic neurons in AD brains. We evaluated the effects of GM1 and A $\beta 1-40$ on mouse neuroepithelial cells. Treatment of these cells simultaneously with GM1 and A $\beta 1-40$ caused a significant reduction of cell number, suggesting that A $\beta 1-40$ and GM1 cooperatively exert a cytotoxic effect on neuroepithelial cells. An understanding of the mechanism on the interaction of GM1 and $\mathrm{A} \beta \mathrm{s}$ in $\mathrm{AD}$ may contribute to the development of new neuroregenerative therapies for this disorder.

\section{Introduction}

Alzheimer's disease $(\mathrm{AD})$ is an irreversible, slowly progressive neurodegenerative disease that is the most common form of dementia among people age 65 and older and is characterized by cognitive and behavioral problems. The symptoms are initiated by memory loss and gradually lead to behavior and personality changes with impaired cognitive abilities such as decline of decision making and language disability, and eventually disturbances in recognizing family and friends. These losses are related to the worsening lesion of the connections between certain neurons in the brain. Patients often become anxious or aggressive, or wander away from home. Eventually, patients need total care, and the final outcome is always death. Although there is no cure at present, some therapeutic drugs inhibiting acetylcholinesterase have been used to alleviate the disease symptoms and improve the quality of life for patients with $\mathrm{AD}[1,2]$.

Gangliosides are important constituents of cells; they are especially abundant in neuronal membranes and play a variety of biological functions, including cellular recognition and adhesion as well as signaling [3]. The expression of gangliosides is not only cell type specific and developmentally regulated but also closely related to the differentiation state of the cell [3-6]. Numerous studies have indicated that changes of ganglioside expression patterns and levels during cellular differentiation are closely related to their metabolism, particularly their biosynthesis $[3,4,6]$. Notably, gangliosides may have neuroprotective effects to the cell [7]. Gangliosides do not function as a neurotrophic factor themselves, but they potentiate neurotrophic influences present in the nervous system. In this regard, many scientists have reported the beneficial effects of GM1 treatment in animal models of neurodegeneration and diseases. For example, administration of GM1 protects hippocampal progenitor cells from neuronal injury and reduces hippocampal neurogenesis induced by D-galactose treatment [8]. Saito et al. reported that GM1 and LIGA20 can protect mouse brains from apoptotic neurodegeneration induced by ethanol [9]. In clinical applications or animal studies, many studies have 
demonstrated the neuroprotective effects of GM1 in diseases such as $\mathrm{AD}[10]$, AD model of transgenic mice [11, 12], Parkinson disease [13], stroke [14], and Guillain-Barré syndrome [15].

The pathological hallmarks in the $\mathrm{AD}$ brain include senile plaques (SPs) and neurofibrillary tangles. Many scientists believe that the accumulation and aggregation of amyloid $\beta$-proteins $(\mathrm{A} \beta \mathrm{s})$ in SPs in the brain are a central part of the pathogenesis of $\mathrm{AD}$. The conversion of soluble, nontoxic $\mathrm{A} \beta$ into aggregated, toxic $\mathrm{A} \beta$ rich in $\beta$-sheet structures is considered to be the key step in the development of $\mathrm{AD} . \mathrm{A} \beta \mathrm{s}$ are able to bind to a variety of biomolecules, including lipids, proteoglycans, and certain proteins $[1,16]$. Immunochemical studies revealed that $\mathrm{A} \beta$ deposits in $\mathrm{AD}$ brain are due to the presence of certain amyloid-associated proteins such as amyloid $\mathrm{P}$ component, proteoglycans, and apolipoproteins [17]. The potential significance of the interaction with proteoglycans and $\mathrm{A} \beta \mathrm{s}$ for the pathogenic mechanisms has been reviewed [2].

During aging and neurodegeneration in $\mathrm{AD}$, the physicochemical properties of membranes and lipid metabolism undergo significant alterations [18, 19]. These include multiple changes such as glycosphingolipid (GSL) abnormalities and impairment of neurotrophin signaling, protein trafficking, and protein turnover [20]. These changes can result in imbalances in the proportion of lipids in membranes and/or changed ratios of membrane lipids, which may contribute to the pathogenesis of AD [21-23]. Earlier immunohistochemical studies on the involvement of GSLs using specific monoclonal antibodies revealed that SPs contained GM1 [24], c-series gangliosides [25], and GD1a [26], and these studies implicate that $\mathrm{A} \beta \mathrm{s}$ might be interacting with the above gangliosides. In this paper, we will focus on the role of ganglioside metabolism in the pathogenesis and/or development of AD.

\section{Interaction of Amyloid $\beta$-Proteins with Gangliosides}

A critical question concerning the development of $\mathrm{AD}$ is how the soluble, nontoxic A $\beta$ form high in an $\alpha$-helix-rich structure is converted into an aggregated, toxic form rich in $\beta$-sheets in the brain. Terzi et al. first reported that $\mathrm{A} \beta 1-40$ undergoes a conformational transition from random coil to aggregated structure rich in $\beta$-sheet after addition of lipid vesicles containing negatively charged lipids [27], suggesting that $\mathrm{A} \beta$ neurotoxicity may be the result of membrane protein-lipid interactions. Several studies have demonstrated that $\mathrm{A} \beta \mathrm{s}$ bind to gangliosides, especially GM1, resulting in an altered secondary structure of $\mathrm{A} \beta \mathrm{s}[28-31]$. $\mathrm{A} \beta$ binds to membranes containing ganglioside GM1, and upon binding it undergoes a conformational transition from random coil to an ordered structure rich in $\beta$-sheet. This interaction appears to be ganglioside-specific because no changes in A $\beta 1-40$ conformation were found in the presence of various phospholipids or sphingomyelin. $\mathrm{A} \beta$ binds selectively to gangliosides with a binding affinity ranging from $10^{-6}$ to $10^{-7} \mathrm{M}$, depending on the type of the sugar moiety present in the ganglioside molecule. On the other hand, the isolated oligosaccharide moieties of gangliosides are ineffective in inducing alterations in the secondary structure of $\mathrm{A} \beta 1-40$ $[28,32]$, suggesting the involvement of the lipid component in their interaction. The sialic acid (NeuAc) moiety of gangliosides interacts with $\mathrm{A} \beta$ to induce conformational changes in $A \beta$ [31]. In this regard, we have reported that $\mathrm{A} \beta 1-40$ binds to a number of gangliosides with the following order of binding strength: GQ1b $\alpha>$ GT1a $\alpha>$ GQ1b $>$ GT1b $>\mathrm{GD} 3>\mathrm{GD} 1 \mathrm{a}=\mathrm{GD} 1 \mathrm{~b}>\mathrm{LM} 1>\mathrm{GM} 1>\mathrm{GM} 2=\mathrm{GM} 3$ $>$ GM4 based on surface plasmon resonance studies [33]. Neutral GSLs, including asialo-GM1, generally have a much lower affinity for $\mathrm{A} \beta 1-40$ than do gangliosides. The results suggest that the $\alpha 2,3 \mathrm{NeuAc}$ residue on the oligosaccharide core of gangliosides is required for binding. In addition, the $\alpha 2,6 \mathrm{NeuAc}$ residue linked to GalNAc in the $\alpha$-series of gangliosides contributes significantly to the binding affinity for $\mathrm{A} \beta$. Although several reports documented the GM1induced alterations in the $\beta$-sheet structure of $\mathrm{A} \beta$, Mandel and Pettegrew, on the other hand, reported that GM1 inhibited $\mathrm{A} \beta$ from undergoing $\alpha$-helix to $\beta$-sheet conformational changes [34]. This discrepancy clearly needs further clarification. In addition, asialo-GM1 binds specifically with $\mathrm{A} \beta$ in a manner that could prevent $\beta$-sheet formation. Nakazawa et al. reported that $\mathrm{A} \beta 1-40$ strongly perturbed the lipid bilayer structure of liposomes of dimyristoylphosphatidylcholine and GM1 to form a nonlamellar phase (most likely in the micellar phase) [35]. The $\alpha$-helical peptide conformation is significantly flexible and is approximately equally partitioned between components penetrated into the bilayer and in liquid phase whereas the $\beta$-sheet peptide conformation is rigid and is presumably deposited and stacked at the bilayer surface.

The interaction between gangliosides and $\mathrm{A} \beta$ appears to be affected by experimental conditions such as $\mathrm{pH}$, ionic strength [30, 31], and metal ions [36, 37]. For example, McLaurin and Chakrabartty have reported that $\mathrm{A} \beta 1-40 / \mathrm{A} \beta 1-42$ disrupts acidic lipid membranes, and this disruption is greater at $\mathrm{pH} 6.0$ than at $\mathrm{pH} \mathrm{7.0,} \mathrm{at} \mathrm{which}$ point gangliosides induce $\mathrm{A} \beta 1-40 / \mathrm{A} \beta 1-42$ to adopt a novel $\alpha / \beta$ conformation [30]. A further study indicated that binding of $\mathrm{A} \beta 1-40$ to mixed gangliosides or GM1-containing vesicles induced an $\alpha$-helical structure at $\mathrm{pH} 7.0$ and $\beta$ structure at $\mathrm{pH} 6.0$ [31]. Several lines of evidence have indicated that disruption of the homeostatic balance of redox-active biometals such as $\mathrm{Cu}$ and $\mathrm{Fe}$ can lead to oxidative stress, which plays a key role in the development of $\mathrm{AD}$. Atwood et al. reported that unlike other biometals tested at maximal biological concentrations, $\mathrm{Cu}^{2+}$-induced aggregation of $\mathrm{A} \beta 1-40$ occurred as the solution $\mathrm{pH}$ was lowered from 7.4 to 6.8 and that the reaction was completely reversible with either chelation or alkalinization [36]. The aggregation-inducing activity of metals is in the following order, $\mathrm{Cu}^{2+}>\mathrm{Fe}^{3+}>$ or $=\mathrm{Al}^{3+}>\mathrm{Zn}^{2+}$ [37].

\section{Binding Sites of Amyloid $\beta$-Proteins with Gangliosides}

The NeuAc residue of the ganglioside head group is important for determining the nature of the conformational change 
of $\mathrm{A} \beta[31,38]$ or interaction with $\mathrm{A} \beta$ [33]. The isolated pentasaccharide head group of GM1 alone, however, does not bind with $A \beta$, suggesting the need for a polyanionic membrane-like structure [38]. To provide a structural basis for this pathogenic interaction associated with $A D$, Williamson et al. have demonstrated using NMR on ${ }^{15} \mathrm{~N}$ labelled $A \beta 1-40$ and $A \beta 1-42$ that the interaction with GM1 micelles is localized to the $\mathrm{N}$-terminal region of the peptide, particularly residues His 13 to Leu17, which become more helical when GM1 is bound [38]. The key interaction is with His13, which undergoes a GM1-specific conformational change. Zhang et al. reported that the binding site for GM1 was located within residues 52-81 ( $\mathrm{N}$ terminus) of amyloid precursor protein (APP), resulting in a conformational change of APP [39]. This phenomenon is specific for GM1, but not for GD1a, GT1b, and ceramide, indicating that specific binding depends on the sugar moiety of GM1.

Utsumi et al. reported the association of $\mathrm{A} \beta 1-40$ isotopically labeled with GM1 and lyso-GM1 micelles using $920 \mathrm{MHz}$ ultra-high field NMR analyses [40]. The data revealed that: (a) A $\beta 1-40$, upon binding to the gangliosidic micelles, forms discontinuous $\alpha$-helices at the segments His(14)-Val(24) and Ile(31)-Val(36), and (b) A $\beta 1-40$ lies on hydrophobic/hydrophilic interface of the ganglioside cluster, exhibiting an up-and-down topological mode in which the two $\alpha$-helices and the C-terminal dipeptide segment are in contact with the hydrophobic interior whereas the remaining regions are exposed to the aqueous environment. These results suggest that the ganglioside clusters serve as a unique platform for binding coupled with conformational transition of $\mathrm{A} \beta$ molecules, rendering their spatial rearrangements restricted to promote specific intermolecular interactions. [40]. Further study of NMR analyses of the $A \beta$ interactions with gangliosides using lyso-GM1 micelles as a model system have revealed that the sugar-lipid interface is primarily perturbed upon binding of $A \beta$ to the micelles, underscoring the importance of the inner part of the ganglioside cluster for accommodating $\mathrm{A} \beta$ in comparison with the outer carbohydrate branches that provide microbial toxin- and virus-binding sites [41].

\section{Accumulation of Specific Ganglioside-Bound Amyloid $\beta$-Protein Complex $($ GA $\beta)$ in AD Brain}

Choo-Smith et al. have reported that addition of gangliosidecontaining vesicles to the $A \beta$ solution dramatically accelerates the rate of fibril formation compared to vesicles without gangliosides [28]. The mechanism of ganglioside-mediated $\mathrm{A} \beta$-fibrillization likely involves an initial step in which the GSL-bound peptide self-associates on the membrane surface, undergoing a conformational transition to a $\beta$-sheet structure. This suggests that gangliosides can mediate $\mathrm{A} \beta$ assembly to lead to accumulation in the brain, which may be involved in the development of AD. Yanagisawa et al. first reported the presence of membrane-bound $A \beta 1-42$, but not $A \beta 1-40$, which tightly binds to GM1 in the AD brain [42]. This novel $\mathrm{A} \beta$ species, named as ganglioside-bound
$\mathrm{A} \beta(\mathrm{GA} \beta)$, may act as an endogenous seed for amyloid [42], and exhibited early pathological changes of $\mathrm{AD}$. It was hypothesized that $\mathrm{A} \beta$ adopts an altered conformation following interaction with GM1, leading to the generation of $\mathrm{GA} \beta$, and then GA $\beta$ acts as an endogenous seed for amyloid in $\mathrm{AD}$ brain. $\mathrm{GA} \beta$ has unique characteristics, including an extremely high aggregation potential and an altered pattern of immunoreactivity, which results in seeding for amyloid fibril formation in brain. Thus, GA $\beta$ may serve as a seed for toxic amyloid fibril formation. The formation of GA $\beta$ serves as one of the critical factors in the development of $\mathrm{AD}$ and may provide new insights into the pathophysiology in $\mathrm{AD}$ [43]. The occurrence of $\mathrm{GA} \beta$ in $\mathrm{AD}$ brain was further confirmed biochemically by staining with cholera toxinB subunit (CTXB) that preferentially binds to GM1, and by immunoprecipitation experiments using several anti-A $\beta$ monoclonal antibodies [44]. Recently, the presence of GA $\beta$ was confirmed in sections of cerebral cortices of cynomolgus monkeys of different ages, from 4 to 36 years old; especially, GA $\beta$ is significantly increased in the brains at ages below 19 years [45]. In this study, the accumulation of GA $\beta$ occurred exclusively in the subcellular organelles that are involved in the endocytic pathway. Since A $\beta$ generation and GM1 accumulation likely occur in early endosomes, it suggests that endosomes are intimately involved in the $\mathrm{A} \beta$-associated pathology of $\mathrm{AD}[45]$. In addition, $\mathrm{A} \beta$ aggregation in brain is accelerated through an increase in the level of GM1 in neuronal membranes $[46,47]$. The effect occurs in a dosedependent manner; in the presence of lower concentrations of GM1 (approximately $25 \mu \mathrm{M}$ ), A $\beta 1-40$ forms aggregates much more slowly, indicating that an increase in the concentration of GM1 significantly facilitates the aggregation of $A \beta$. Further studies have indicated that both GM1 and GT1b promote the aggregation and cytotoxicity of $A \beta 1-$ 40 , and these gangliosides, especially GM1, catalyze the formation of neurotoxic fibrils [48]. Moreover, binding of $A \beta$ to GM1 was dependent on cholesterol-induced clustering of GM1 in the host membranes. An increase in the cholesterol concentration in the neuronal membranes accelerates $A \beta$ aggregation through the formation of an endogenous seed $[49,50]$, consistent with the notion that cholesterol is also a risk factor for $\mathrm{AD}$ development. These results further underscore the importance of control of cellular cholesterol and/or ganglioside contents in the pathogenesis of $\mathrm{AD}$ [5052]. Lin et al. reported the role of GM1 and cholesterol on the $\mathrm{A} \beta$-induced cytotoxicity in the plasma membrane [53]. Depletion of GM1 from the plasma membrane would be expected to block the $\mathrm{A} \beta$-induced cytotoxicity. Decreasing the cholesterol level by around 30\% could also attenuate the cytotoxicity of $A \beta$. These findings validate that cholesterol can stabilize the lateral pressure derived from formation of the GM1-A $\beta$ complex on the membrane surface and that both GM1 and cholesterol are essential for $A \beta$ accumulation. Zha et al. reported that GM1 regulated the expression of $A \beta$ in a dose-dependent manner [54]. Exogenously added GM1 increased $\mathrm{A} \beta$ levels in mixed rat cortical neurons containing African green monkey epithelial kidney cells (COS7) and human neuroblastoma cells (SH-SY5Y) that were transfected with APP695 cDNA. 
Yanagisawa and coinvestigators developed a novel monoclonal antibody, 4396C, raised against GA $\beta$ purified from an $\mathrm{AD}$ brain [55]. Using this antibody, the presence of GA $\beta$ was confirmed in the AD brain, in which GA $\beta$ is endogenously generated. The antibody reacted with GM1-bound forms of two $\mathrm{A} \beta$ isoforms, $\mathrm{A} \beta 1-40$ and $\mathrm{A} \beta 1-42$, but not the unbound forms of $\mathrm{A} \beta 1-40$ and GM1. Remarkably, using liposomes containing $\mathrm{A} \beta 1-40$ and GM1, this antibody completely blocks amyloid fibril formation in a dose-dependent manner, suggesting that it may act to inhibit the initiation of oligomerization-polymerization of $\mathrm{A} \beta$ in the brain and serve in the possible development of a novel therapeutic strategy to the GA $\beta$-dependent amyloidogenesis $[55,56]$. The agedependent high-density GM1 clustering at the presynaptic neuritic terminals is a critical step for $\mathrm{A} \beta$ deposition in $\mathrm{AD}$. In amyloid-positive synaptosomes prepared from AD brain, GM1 levels are significantly increased when $A \beta$ deposition begins at presynaptic terminals. The antibody against GA $\beta$, 4396C, suppressed A $\beta$ assembly in the synaptosomes [57]. Moreover, peripheral administration of the Fab fragments of 4396C into transgenic mice expressing a mutant amyloid precursor protein gene, following the conjugation of the protein transduction domain of the Tat protein, markedly suppressed $\mathrm{A} \beta$ deposition in the brain [58].

Interestingly, the enhanced GA $\beta$-dependent amyloidogenesis under the endocytic dysfunction was suppressed by pretreatment with a sphingomyelinase synthase inhibitor, suggesting that sphingomyelin is also one of the key molecules for GA $\beta$ generation, further implying that the interaction of $\mathrm{A} \beta$ with membrane lipids is critical in amyloid fibrillization in the brain [59]. In addition, the expression of apolipoprotein E4 may facilitate $A \beta$ assembly in the brain through an increase in the GM1 content in neuronal membranes, which likely induces GA $\beta$ generation $[43,47$, 60].

In recent years, evidence has been presented that "lipid rafts" are the preferential sites for the formation of the pathological forms of $A \beta$ [61]. GA $\beta$ is generated in the membrane raft-like microdomains, comprised of cholesterol, sphingomyelin, and GM1 $[62,63]$, in which A $\beta$ undergoes a conformational transition from an $\alpha$-helix-rich structure to a $\beta$-sheet-rich structure or oligomerization with the increase in protein density on the membrane. GM1 induced amyloid fibrillization, especially under $\beta$-sheet-forming conditions, leading to the generation and seeding of GA $\beta$. Thus, ganglioside binding with $\mathrm{A} \beta$ is the initial and common step in the development of a part of human misfolding-type amyloidoses, including $\mathrm{AD}$ [64]. The level of GA $\beta$ is increased, and its $\alpha$-helix structure is converted into a $\beta$-sheet structure [65]. Thus, the formation of amyloid fibrils or oligomers is likely mediated by gangliosides in lipid rafts [66], and depletion of gangliosides or cholesterol significantly reduces the amount of amyloid deposits [48,67].

\section{Other Gangliosides May Be Involved In the Generation of GA $\beta$}

Other gangliosides have been shown to interact with $\mathrm{A} \beta$, which may lead to $\mathrm{A} \beta$ accumulation in the brain. The assembly of wild-type and mutant forms of Arctic-, Dutch-, and Flemish-type of $A \beta s$ is accelerated in the presence of not only GM1, but also GM3 and GD3 gangliosides. Dutch and Italian-type $\mathrm{A} \beta \mathrm{s}$ require GM3 ganglioside for their assembly [47]. Arctic-type A $\beta$, in contrast to the wildtype and other variant forms, shows a markedly rapid and higher level of amyloid fibril formation in the presence of sodium dodecyl sulfate or GM1 ganglioside [68]. These results provide evidence that local gangliosides play a crucial role in the region-specific $\mathrm{A} \beta$ deposition in the brain [69, 70]. Gangliosides are located mostly on the cell surface and have been demonstrated to modulate neurotrophic activities. The localization of GD1a in dystrophic neurites suggests that such neurites accumulate GDla as a membranous component. In addition, the accumulation of GD1a in SPs suggests that it may contribute to SP formation [26]. In a study for the interaction of $\mathrm{A} \beta \mathrm{s}$ with GM1 using rat adrenal medulla pheochromocytoma cells (PC12 cells), Wakabayashi et al. used CTXB for detection of GM1 [71]. However, the ganglioside that interacted with $\mathrm{A} \beta \mathrm{s}$ in $\mathrm{PC} 12$ cells may not be definitely GM1 because CTXB also strongly reacted also with fucosyl-GM1 and fucosyl-GD1b [72] and PC12 cells express fucosyl gangliosides including fucosyl-GM1 [73, 74] with little or no GM1 [75]. When PC12 cells were cultured in the presence of $\mathrm{A} \beta 1-40$ or $\mathrm{A} \beta 1-42, \mathrm{~A} \beta$ s accumulated in cells expressing fucosyl gangliosides [72]. Thus, the interaction of $\mathrm{A} \beta$ with gangliosides to effect amyloid assembly may not be limited to GM1; indeed, other gangliosides should also be involved in "seeding" [1, 72]. Molander-Melin et al. reported that the detergent-resistant membrane fractions from the frontal cortex of AD brains contained a significantly higher concentration of ganglioside GM1 and GM2 [76]. The increased proportions of GM1 and GM2 in lipid rafts at an early $\mathrm{AD}$ stage could accelerate the formation of $\mathrm{A} \beta$ plaques, which gradually causes membrane raft disruptions and thereby affects cellular functions that are dependent on the presence of such membrane domains.

\section{Ganglioside Metabolism in AD Brains and AD Model Mouse Brains}

$\mathrm{A} \beta$ changes in membrane fluidity could be induced by chemical interactions of the peptide with membrane components such as cholesterol, phospholipids, and gangliosides [77]. Since gangliosides have a strong affinity to $A \beta s$ [33], they could participate in conformational changes of $A \beta s$ in membrane fluidity. For this reason, ganglioside metabolism has been considered to be closely associated with the pathogenesis of $\mathrm{AD}[1,20]$. Several earlier studies showed significant changes of ganglioside patterns in $\mathrm{AD}$ brain. The concentration of gangliosides decreased in the majority of brain regions, such as the cerebral cortex, hippocampus, and basal telencephalon, especially in the frontal cortex and white matter [78-80]. Kracun et al. reported that the major brain ganglio-N-tetraosyl-series ganglioside species (GT1b, GD1b, GD1a, and GM1) significantly decreased in the frontal and temporal cortices and basal telencephalon of the brains of patients with $\mathrm{AD}$ compared with the respective areas in control brain $[81,82]$. Brooksbank and 


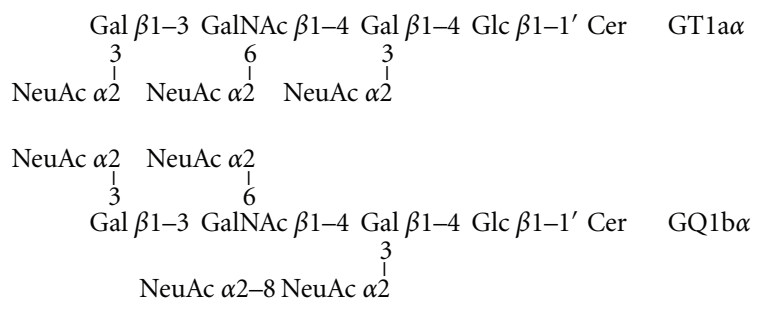

Scheme 1

McGovern [83] and Crino et al. [84] also reported changes of ganglioside composition in $\mathrm{AD}$ brains in which b-series gangliosides, such as GT1b and GD1b, showed a significant decrease, in contrast to a slight increase in GT1a, GD3, GM1, and GM2. These findings suggest that abnormal ganglioside metabolism coincides with the affected cortical areas of neurodegeneration that afflicts $\mathrm{AD}$.

In contrast to these human studies, we found no significant differences in the lipid-bound NeuAc content in the brain slices containing hippocampal/cortical tissue prepared from $\mathrm{AD}$ model double transgenic $(\mathrm{Tg})$ mice coexpressing mouse/human chimeric APP with the Swedish mutation and human presenilin-1 with a deletion of exon 9 and agematched wild-type (WT) mice, even though $\mathrm{A} \beta \mathrm{s}$ were found to be accumulated in the brain (Figure 1) and serum of these $\mathrm{Tg}$ AD model mice [85]. In addition, there was no significant difference in the expression levels of major gangliosides (GM1, GD1a, GD1b, and GT1b) in the brains between double Tg and age-matched WT mice. This is consistent with the report by Sawamura et al. [86] who also did not detect notable changes in the major gangliosides in the brain of mutant presenilin-2 $\mathrm{Tg}$ mice, despite the remarkable increase in the level of $A \beta 1-42$ and statistically significant lower levels of glycerophospholipids and sphingomyelin. In addition, Bernardo et al. also did not find significant differences in a- or b-series gangliosides between WT and double Tg mice expressing APP with the Swedish mutation and presenilin1 with a deletion of exon 9 [87]. These studies as well as our recent data indicate no significant changes in the major brain ganglioside metabolism in $\mathrm{AD}$ model mice, despite the presence of massive accumulation of $\mathrm{A} \beta$ deposits in the brains of these animals. Barrier et al. reported an increase of GM2 and GM3 within the cortices of Tg mice expressing human APP751 with Swedish and London mutations and human presenilin-1 (M1461) [88].

The most consistent and interesting finding of our recent study is the increased expression of cholinergic-specific antigen- $1 \alpha$ (Chol- $1 \alpha$ ) antigens, GT1a $\alpha$, and GQ1b $\alpha$ (see Scheme 1), especially GQ1b $\alpha$, in the brain of double Tg mice as compared with those in WT mouse brains (Figure 2). The increase was especially significant in female double $\mathrm{Tg}$ mouse brains. No significant differences were found in the expression of GT1a $\alpha$ and GQ1b $\alpha$ between male and female WT mouse brains. These gangliosides are normally minor species in the brain and serve as markers of cholinergic neurons $[89,90]$. The expression of Chol- $1 \alpha$ antigens in rat brain regions such as the hippocampus is developmentally regulated, and their concentrations increase with aging [91]. Although the functional role of Chol- $1 \alpha$ antigens in $\mathrm{Tg}$ mice brain has remained obscure, Ando et al. reported that the release of acetylcholine from synaptosomes was inhibited by anti-Chol-1 $\alpha$ monoclonal antibody [92]. The memory and learning abilities of rats given anti-Chol- $1 \alpha$ antibody were remarkably suppressed. On the contrary, the treatment of Chol- $1 \alpha$ antigen induced choline uptake by synaptosomes. As a result of increased choline uptake, acetylcholine synthesis was enhanced by Chol- $1 \alpha$ antigens. Chol- $1 \alpha$ antigens are specifically expressed in the cholinergic neutrophil and may participate in cognitive functions such as memory and learning. Beneficial effects of Chol- $1 \alpha$ antigens were shown to ameliorate decreased functions of synapses from aged brains, suggesting that Chol- $1 \alpha$ antigens may play a pivotal role in cholinergic synaptic transmission and participates in cognitive function [93]. Interestingly, Chapman et al. reported the presence of serum antibody in patients with $\mathrm{AD}$ that specifically bind to cholinergic neurons [94]. The increasing antibody in the patient's sera may be attributed to the increase of Chol- $1 \alpha$ antigens in $\mathrm{AD}$ brain. Cholinergic neuronal dysfunction of basal forebrain is observed in patients with $\mathrm{AD}$, and has been linked to decreased neurogenesis in the hippocampus, a region involved in learning and memory [95]. They recently found an increasing number of newborn cells in the dentate gyrus of hippocampus in cholinergic-denervated mice compared to nonlesioned mice, suggesting neurogenesis can occur in $\mathrm{Tg}$ mice brain to generate new cells expressing Chol$1 \alpha$ antigens. It would be extremely interesting to enhance neurogenesis in hippocampus of patients and animal models of $\mathrm{AD}$ [96-99].

In addition to the above, AD model animals with disrupted ganglioside biosynthesis have been reported to reveal relationships between ganglioside metabolism and aspects of AD. For example, Oikawa et al. crossbred Tg mice expressing human APP having Swedish and London mutations with GM2-synthase knockout mice [100]. The mutant mice expressing GM3 and GD3, but not GM1, GD1a, GD1b, and GT1b, showed a significant increase of $A \beta$ accumulation in vascular tissues and formation of severe dysphonic-form amyloid angiopathy in the brain. In contrast, Bernardo et al. analyzed the AD model of Tg mice expressing APP with the Swedish mutation and presenilin-1 with a deletion of exon 9 that crossbred with mice deficient in GD3-synthase, which catalyzes the synthesis of b-series gangliosides [87]. In the triple mutant mice, b-series gangliosides, including GD3, were completely absent, but GM1 and GD1a were significantly increased. Interestingly, $A \beta$ plaques and associated neuropathology were almost completely eliminated in the triple mutant mice, resulting in cognitive improvement [87]. These observations suggest that b-series gangliosides synthesized by GD3-synthase are one of the major causes of $A \beta$ accumulation and AD. Thus, inhibition of GD3-synthase can be a novel therapeutic target to combat the cognitive deficits, amyloid plaque formation, and neurodegeneration seen in $\mathrm{AD}$.

In this regard, Okada et al. reported that endogenously generated b-series gangliosides may be critical for 

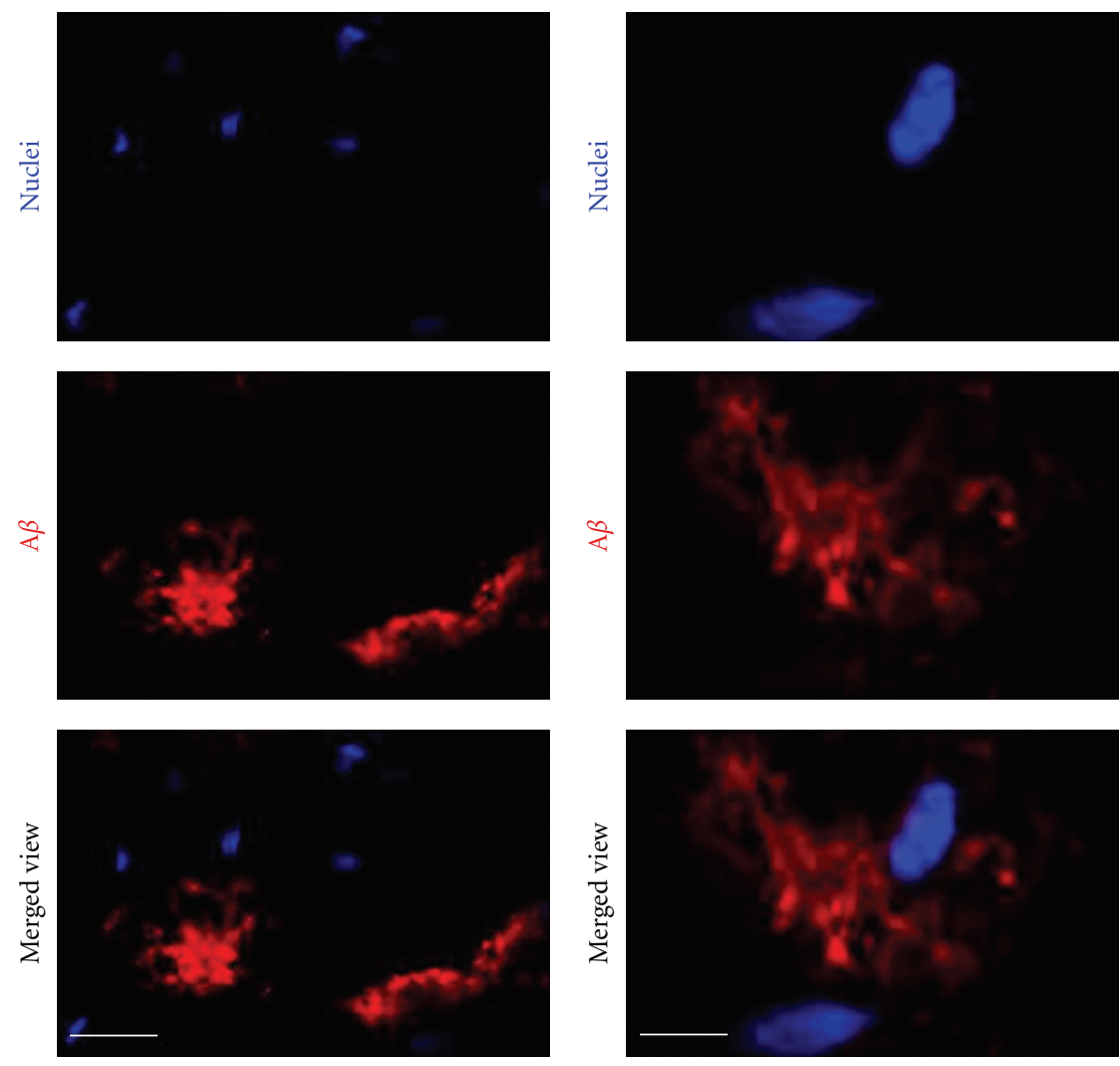

(a)

(b)

FIGURE 1: Immunohistochemical localization of A $\beta$ s in the cortex of double transgenic mice coexpressing mouse/human chimeric APP with the Swedish mutation and human presenilin-1 with deletion of exon 9. The coronal brain sections are $12 \mu \mathrm{m}$ in thickness. Nuclei (blue) and $\mathrm{A} \beta$ (red) were stained with Hoechst 33258 and antihuman $\mathrm{A} \beta$ antibody, respectively. (a) low-magnification view; (b) high-magnification view. Bar $=20 \mu \mathrm{m}$ in (a); $5 \mu \mathrm{m}$ in (b). (Reproduced from [85] with permission).

the repair of damaged neural tissues in vivo [101]. They established a GD3-synthase gene knockout mouse model in which all b-series gangliosides were deleted. However, animals showed no morphological changes in the brains and apparent abnormal behavior. Moreover, no differences in Fas-mediated apoptotic reaction in lymphocytes compared with the wild type were found. The mutant mice, however, exhibited reduced regeneration of axotomized hypoglossal nerves compared with the wild type, suggesting that b-series gangliosides are more important in the repair of damaged nerves rather than in the differentiation of the nervous system.

\section{Neurogenesis and Neural Stem Cells in AD Brain}

The neurodegenerative process in $\mathrm{AD}$ is initially characterized by synaptic damage accompanied by neuronal loss. Neuronal loss leads to cerebral atrophy, which appears to be hallmarks of cognitive impairment in $\mathrm{AD}$ [102]. In addition to the alterations in synaptic plasticity and neuronal integrity in mature neuronal circuitries, the neurodegenerative process in $\mathrm{AD}$ has recently been shown to be accompanied by alterations in neurogenesis $[103,104]$. The hippocampus is one of the regions in the adult brain where neurogenesis occurs throughout life [5]. Many studies have shown that adult neurogenesis is involved in learning and memory. This has led to the hypothesis that impairment in memory during aging and neurodegenerative diseases such as $\mathrm{AD}$ involves abnormal neurogenesis [105]. However, neurogenesis in AD and in animal models is not fully studied yet [106]. In AD brains, there is some controversy whether neurogenesis is increased [107] or decreased [107]. Boekhoom et al. reported an apparent increase of neurogenesis markers in AD brains, which may be related to glial and vasculature-associated changes [107]. A number of mouse models of AD displayed reduced neurogenesis [108-110] or enhanced neurogenesis [97]. Several attributes of adult hippocampal neurogenesis suggest that amyloid deposition may influence neurogenesis [111]. Zhang et al. reported that reductions in dentate gyrus neurogenesis in a murine model of amyloid deposition are linked to the deposition of amyloid [112].

The adult mammalian brain contains neural stem cells (NSCs), undifferentiated neural cells characterized by their high proliferative potential and the capacity for self-renewal with retention of multipotency to differentiate into neurons and glial cells, in the subgranular zones of dentate gyrus 


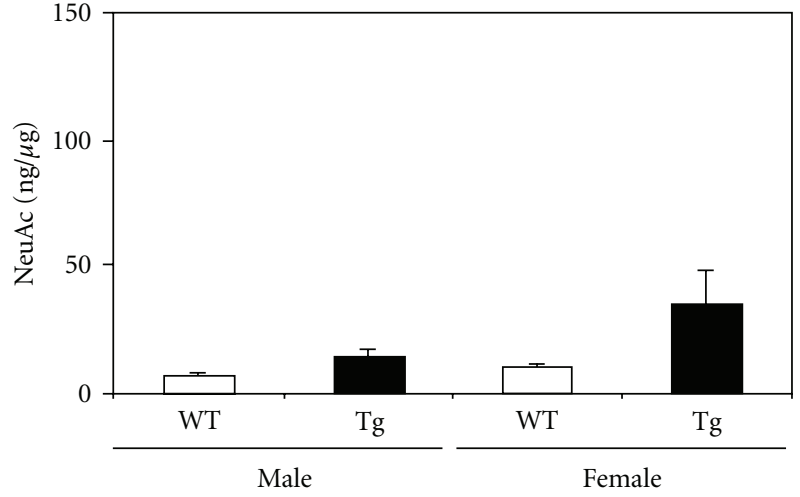

(a) GTla $\alpha$

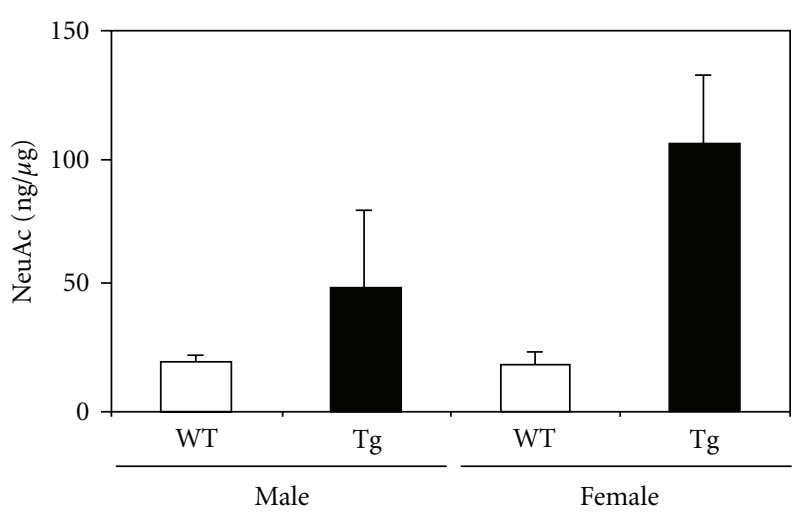

(b) GQ1b $\alpha$

FIgURE 2: The content of Chol-1 $\alpha$ antigens, GT1a $\alpha$ (a) and GQ1b $\alpha$ (b), in AD model mouse brains [85]. GT1a $\alpha$ and GQ1b $\alpha$ extracted from brains of AD model double transgenic mice coexpressing mouse/human chimeric APP with the Swedish mutation and human presenilin-1 with a deletion of exon $9(\mathrm{Tg})$ or age-matched wild-type mice (WT) were quantified by densitometric analysis of high-performance thinlayer chromatography immunostaining. $n=3-7$. (Reproduced from [85] with permission).

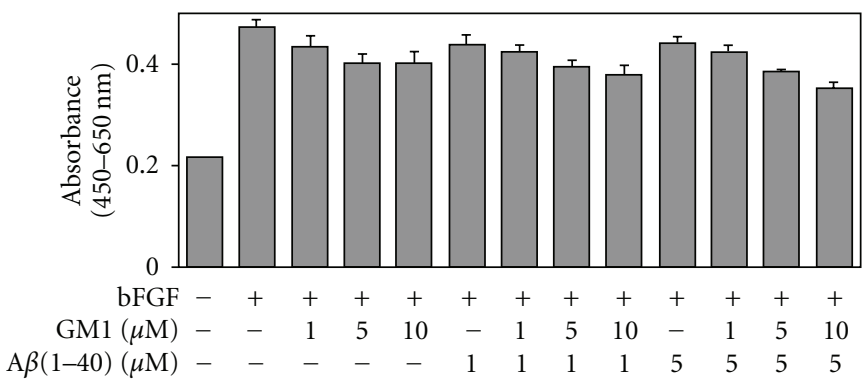

(a)

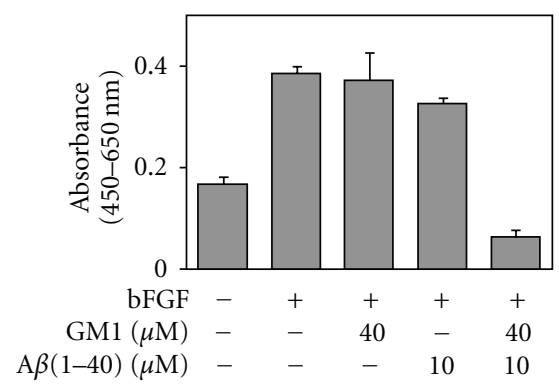

(b)

Figure 3: Effects of low (a) and high (b) concentrations of GM1 and A $\beta 1-40$ on NECs. Basic fibroblast growth factor (bFGF; 0 or 5 ng/mL) was added as a mitogen of NECs. The number of NECs cultured in the presence of bFGF for 4 days was estimated by WST-8 assay with (a) GM1 $(0,1,5$ or $10 \mu \mathrm{M})$ and $\mathrm{A} \beta 1-40(0,1$ or $5 \mu \mathrm{M})$; with (b) GM1 $(0$ or $40 \mu \mathrm{M})$ and $\mathrm{A} \beta 1-40(0$ or $10 \mu \mathrm{M})$. The spectrophotometric absorbance (Abs.) measured at the wavelength of $450 \mathrm{~nm}$ (reference, $650 \mathrm{~nm}$ ) by this assay is highly correlated with the number of living NECs [113]. (Reproduced from [114] with permission).

and the subventricular zone (SVZ) of the lateral ventricles [5]. The possibility that abnormalities in NSCs contribute to the pathogenesis of $\mathrm{AD}$ and the cognitive impairments in humans has been suggested $[109,110]$. Several papers have described the phenomenon of neurogenesis in hippocampus, and it seems to be enhanced in AD brains. This phenomenon could potentially occur also in the brain of animal models of $\mathrm{AD}$, which points to the possibility of developing strategies for promoting neurogenesis for AD therapy by using NSCs. A number of studies have indicated that $A \beta$ s can regulate the proliferation of NSCs and documented the bifunctional roles of $A \beta s$ on the cells in a dose-dependent manner. The low concentrations of $A \beta$ s have neurogenic effects in some studies [115-117] but cytotoxic effects in other studies [109, $118,119]$. Soluble oligomers of $A \beta 1-40$ and $A \beta 1-42$, but not $\mathrm{A} \beta 40-1$, a reversed amino acid sequence, induced neuronal apoptosis [120]. the aggregated form of $A \beta 1-42$ stimulated neurogenesis $[117,121]$. In this regard, $A \beta 1-40(0.5 \mu \mathrm{mol} / \mathrm{L})$ significantly reduced proliferation of endothelial progenitor cells by about $65 \%$ compared to control whereas $A \beta 40-1$
$(0.5 \mu \mathrm{mol} / \mathrm{L})$, did not affect their proliferation [122]. Gong et al. reported that small, soluble oligomers of $A \beta$ block the reversal long-term potentiation [123]. Controversially, a low micromolar concentration $(1 \mu \mathrm{M})$ of oligomeric $\mathrm{A} \beta 1-$ 42 increased the proliferation [124] and neurogenesis of adult NSCs [117]. Small peptide, A $\beta 1-16$, had no effect on neuronal proliferation of adult SVZ progenitors [119, 121] Several studies indicated that $A \beta 25-35$ has toxic effects and may induce cell death or apoptosis $[109,110,118$, $125,126]$. In contrast, $\mathrm{Li}$ and Zuo reported inhibitory effects of aggregated form of A $\beta 25-35(1 \mathrm{mg} / \mathrm{mL}, 3 \mu \mathrm{L})$ on neurogenesis in the SVZ and dentate gyrus after injection into the lateral ventricle of adult mouse [127]. This result indicates that $A \beta 25-35$ could impair neurogenesis in the hippocampus of adult mouse brain.

In neuronal cultures prepared from rat hippocampi (embryonic day 18 to 19 ), it was reported that $25 \mu \mathrm{M}$ of A $325-35$ enhanced the metabolism of lipids such as phospholipids (+52\%) and gangliosides (+193\%), but not cholesterol [128]. In addition, exposure of rat cultured cortical 

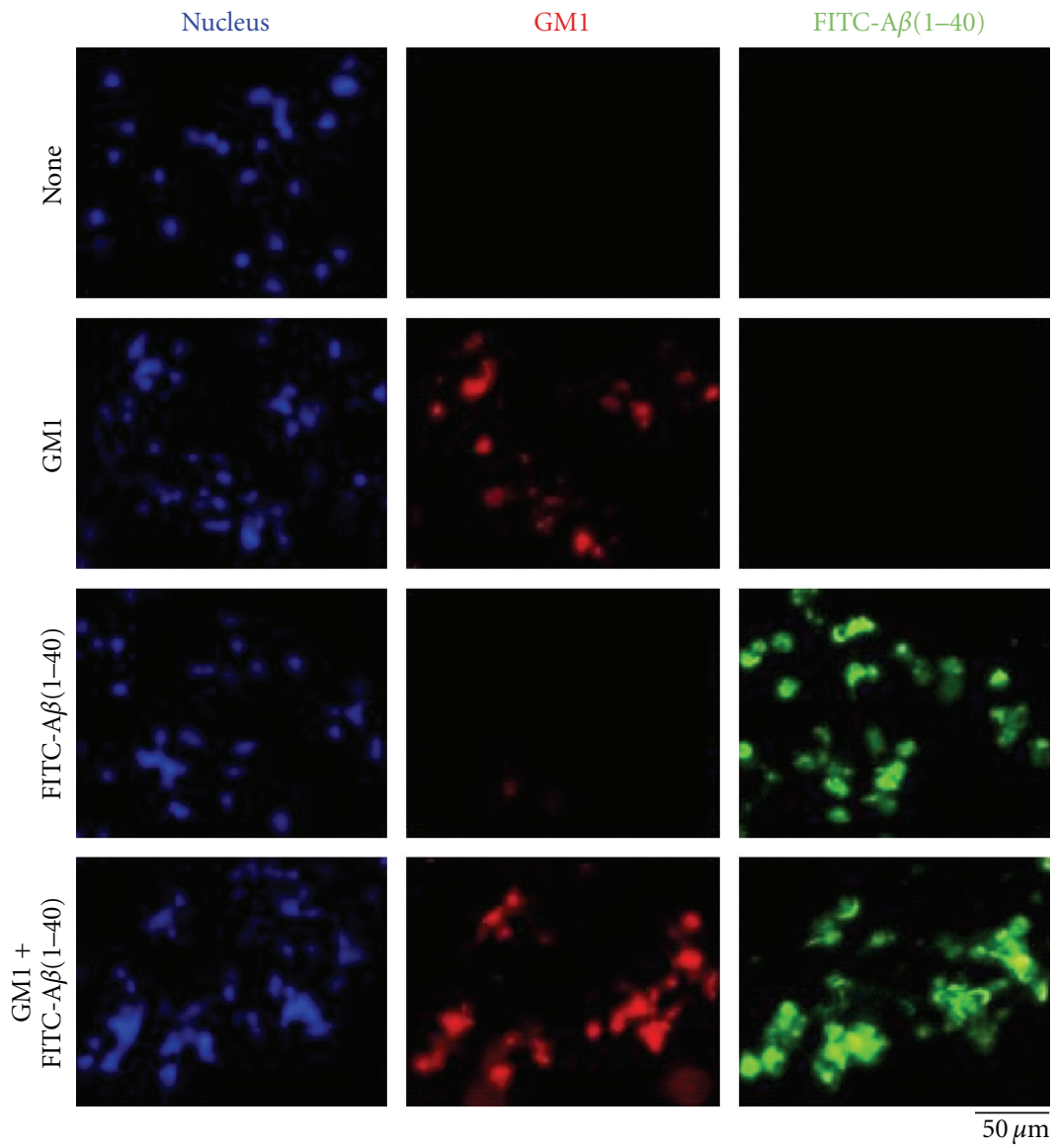

FIGURE 4: Incorporation of exogenously added GM1 and A $\beta 1-40$ into NECs. NECs were cultured in the presence of GM1 ( 0 or $40 \mu \mathrm{M})$ and/or fluorescein isothiocyanate-conjugated $\mathrm{A} \beta 1-40$ (FITC-A $\beta 1-40 ; 0$ or $10 \mu \mathrm{M})$ for 2 days, and then stained with biotin-conjugated CTXB, a probe to detect GM1, and rhodamine-conjugated streptavidin. Nuclei were stained with Hoechst 33258. (Reproduced from [114] with permission).

neurons to $A \beta 25-35$ induced a substantial increase of the intracellular GD3 levels [129]. These reports suggest that $\mathrm{A} \beta$ can modulate ganglioside metabolism in NSCs. It has been reported that in NSCs, GSLs, including gangliosides, are involved in cellular proliferation via modulation of the Ras-mitogen-activated protein kinase pathway [114]. These findings prompt us to propose that a combination of $\mathrm{A} \beta$ and GM1 induces NSC proliferation. Recently, we evaluated the effects of GM1 and A $\beta 1-40$ on mouse neuroepithelial cells (NECs) that are known to be abundant in NSCs [130]. In NECs cultured in the presence of lower concentrations of $\operatorname{GM} 1(1,5$ or $10 \mu \mathrm{M})$ and/or $\mathrm{A} \beta 1-40(1$ or $5 \mu \mathrm{M})$, there was no drastic change of the cell number (Figure 3(a)). However, in NECs cultured in the presence of both $40 \mu \mathrm{M}$ of GM1 and $10 \mu \mathrm{M}$ of $\mathrm{A} \beta 1-40$, a significant reduction of the cell number was detected (Figure 3(b)). These exogenously added GM1 and $A \beta 1-40$ were efficiently incorporated into NECs (Figure 4). In NECs simultaneously treated with GM1 and A $\beta 1-40$, the Ras-mitogen-activated protein kinase pathway important for proliferation was intact, but caspase-3, an executioner for cell death, was activated. Most NECs treated with GM1 and A $\beta 1-40$ were positive for terminal deoxynucleotidyl transferase-mediated dUTP nickend labeling, an indicator of cell death accompanied with
DNA fragmentation. These results indicate that $A \beta 1-40$ and GM1 cooperatively exert a cytotoxic effect on NECs, likely via incorporation into NEC membranes where the formation of a complex results in activation of cell death signaling.

Several reports have indicated that gangliosides added exogenously in the culture medium have bifunctional effects on neural cell proliferation. Gangliosides added exogenously at the concentration of micromolar levels were found to inhibit neuritogenesis in human neuroblastoma cells, SHSY5Y [131]. However, under physiological conditions, GM1 enhanced nerve growth factor-induced neurite outgrowth, neurite complexity, and neuronal cell survival following nerve growth factor withdrawal using fetal-chick dorsal root ganglia [132] and induced neurite sprouting in culture neurons [133]. GQ1b induced phosphorylation of cell surface proteins in a human neuroblastoma cell line, GOTO [134]. The effects of gangliosides exogenously added remained obscure and seem to vary from one cell line to another and the culture conditions [7]. Therefore, further studies are needed to clarify the relationship between GM1 and $A \beta$ in the proliferation of NECs. In addition, evaluation of the effects of exogenous GM1 on neurogenesis and pathogenesis of $\mathrm{AD}$ in pathological conditions, for instance, using $\mathrm{AD}$ model mice [135] will be an interesting and fruitful subject for future 
studies. Many studies showed that NSCs improved neuronal survival in cultured postmortem brain tissue from aged and $\mathrm{AD}$ patients [136]. Further studies to understand the roles of GM1 and $A \beta s$ on NSCs in AD should contribute to the development of new regenerative therapies of this disease.

\section{Conclusions}

There is increasing consensus that $\mathrm{AD}$ is characterized in the brain by aggregated amyloid deposits in SPs. The aggregation of $\mathrm{A} \beta$ plays a pivotal role in the pathogenesis of $\mathrm{AD}$ that is intimately linked to neuronal toxicity and inhibition of hippocampal long-term potentiation. At present, there is no cure for $\mathrm{AD}$, although some drugs inhibiting acetylcholinesterase have proved to be current treatment to palliate both cognitive and behavioral symptoms within a limited time. Researchers are looking for new treatments to alter the course of the disease and improve the quality of life for patients with $\mathrm{AD}$ and related dementia. $\mathrm{A} \beta$ is currently clarified to interact with gangliosides with high affinities. In fact, a complex of GM1 (and possibly other gangliosides) with $A \beta$, termed $G A \beta$, was found to accumulate in the $\mathrm{AD}$ brains. An antibody against GA $\beta$ was proved to block amyloid fibril formation, suggesting that it can contribute to the development of a novel therapeutic strategy to AD. In this regard, drugs such as nordihydroguaiaretic acid, rifampicin, and tannic acid are found to be potent inhibitors of the binding of GM1 and $A \beta$, resulting in inhibition of membrane-mediated formation of $\mathrm{A} \beta$ fibrils in vitro. These drugs are useful agents for $\mathrm{AD}$ therapy [137]. On the other hand, in AD model mice lacking GD3-synthase, $\mathrm{A} \beta$ plaques and associated neuropathology are almost completely eliminated, resulting in cognitive improvement. GD3synthase and its downstream metabolic products, the bseries gangliosides, can be a novel therapeutic target for repressing neurodegeneration and cognitive deficits that afflict $\mathrm{AD}$ patients. Another promising therapeutic strategy for AD is cell replacement therapy using NSCs. Although neurogenesis in AD brains is still controversial, transplantation of NSCs into the damaged brain regions may be beneficial for neural regeneration in $\mathrm{AD}$. For therapeutic use of NSCs in AD, however, it should be essential to fully clarify the effects of $\mathrm{A} \beta \mathrm{s}$ and gangliosides on NSC fate regulation. Future therapies for treating $\mathrm{AD}$ will include agents that modulate GSL metabolism, either as primary therapeutics or in combination with other drugs.

The nomenclature for gangliosides is based on the system of Svennerholm [138].

\section{Abbreviations}

A $\beta$ : $\quad$ Amyloid $\beta$-protein

AD: $\quad$ Alzheimer's disease

APP: Amyloid precursor protein

Chol- $1 \alpha$ : Cholinergic-specific antigen- $1 \alpha$

CTXB: Cholera toxin B-subunit
$\mathrm{Ga} \beta$ : $\quad$ Ganglioside-bound $\mathrm{A} \beta$ or a complex of GM1 and $\mathrm{A} \beta$

GSL: Glycosphingolipid

NEC: Neuroepithelial cell

NSC: Neural stem cell

SVZ: Subventricular zone

NeuAc: Sialic acid or $\mathrm{N}$-acetyl neuraminic acid

SP: $\quad$ Senile plaque

Tg: $\quad$ Transgenic

WT: Wild type.

\section{Acknowledgments}

This study was supported by USPHS Grants (nos. NS11853, NS26994, and AG027199) to R. K. Yu. The authors are grateful to Dr. Susumu Ando (Tokyo Metropolitan Institute of Gerontology, Japan) for supplying the Chol- $1 \alpha$ antigens and the monoclonal antibodies and Dr. Makoto Yanagisawa, Medical College of Georgia, GA for helpful discussions in preparation of this paper.

\section{References}

[1] T. Ariga, M. P. McDonald, and R. K. Yu, "Role of ganglioside metabolism in the pathogenesis of Alzheimer's disease-a review," Journal of Lipid Research, vol. 49, no. 6, pp. 11571175, 2008.

[2] T. Ariga, T. Miyatake, and R. K. Yu, "Role of proteoglycans and glycosaminoglycans in the pathogenesis of Alzheimer's disease and related disorders: amyloidogenesis and therapeutic strategies-a review," Journal of Neuroscience Research, vol. 88, no. 11, pp. 2303-2315, 2010.

[3] R. K. Yu, Y. Nakatani, and M. Yanagisawa, "The role of glycosphingolipid metabolism in the developing brain," Journal of Lipid Research, vol. 50, pp. S440-S445, 2009.

[4] S. Ngamukote, M. Yanagisawa, T. Ariga, S. Ando, and R. K. Yu, "Developmental changes of glycosphingolipids and expression of glycogenes in mouse brains," Journal of Neurochemistry, vol. 103, no. 6, pp. 2327-2341, 2007.

[5] M. Yanagisawa and R. K. Yu, "The expression and functions of glycoconjugates in neural stem cells," Glycobiology, vol. 17, no. 7, pp. 57R-74R, 2007.

[6] R. K. Yu, "Development regulation of ganglioside metabolism," Progress in Brain Research, vol. 101, pp. 31-44, 1994.

[7] R. W. Ledeen, G. Wu, Z. H. Lu, D. Kozireskichuback, and Y. Fang, "The role of GM1 and other gangliosides in neuronal differentiation: overview and new findings," Annals of the New York Academy of Sciences, vol. 845, pp. 161-175, 1998.

[8] Q. Zhang, Y. Huang, X. Li, X. Cui, P. Zuo, and J. Li, "GM1 ganglioside prevented the decline of hippocampal neurogenesis associated with D-galactose," NeuroReport, vol. 16, no. 12, pp. 1297-1301, 2005.

[9] M. Saito, R. F. Mao, R. Wang, C. Vadasz, and M. Saito, "Effects of gangliosides on ethanol-induced neurodegeneration in the developing mouse brain," Alcoholism: Clinical and Experimental Research, vol. 31, no. 4, pp. 665-674, 2007.

[10] L. Svennerholm, G. Bråne, I. Karlsson, A. Lekman, I. Ramström, and C. Wikkelsö, "Alzheimer disease-effect of continuous intracerebroventricular treatment with GM1 
ganglioside and a systematic activation programme," Dementia and Geriatric Cognitive Disorders, vol. 14, no. 3, pp. 128136, 2002.

[11] K. Kawaguchi, N. Kitaguchi, S. Nakai et al., "Novel therapeutic approach for Alzheimer's disease by removing amyloid $\beta$ protein from the brain with an extracorporeal removal system," Journal of Artificial Organs, vol. 13, no. 1, pp. 31-37, 2010.

[12] Y. Matsuoka, M. Saito, J. LaFrancois et al., "Novel therapeutic approach for the treatment of Alzheimer's disease by peripheral administration of agents with an affinity to $\beta$-amyloid," Journal of Neuroscience, vol. 23, no. 1, pp. 29-33, 2003.

[13] J. S. Schneider, D. P. Roeltgen, E. L. Mancall, J. ChapasCrilly, D. S. Rothblat, and G. T. Tatarian, "Parkinson's disease improved function with GM1 ganglioside treatment in a randomized placebo-controlled study," Neurology, vol. 50, no. 6, pp. 1630-1636, 1998.

[14] G. L. Lenzi, F. Grigoletto, M. Gent et al., "Early treatment of stroke with monosialoganglioside GM-1: efficacy and safety results of the early stroke trial," Stroke, vol. 25, no. 8, pp. 1552-1558, 1994.

[15] R. A. Hughes and D. R. Cornblath, "Guillain-Barré syndrome," The Lancet, vol. 366, no. 9497, pp. 1653-1666, 2005.

[16] Y. Verdier and B. Penke, "Binding sites of amyloid $\beta$-peptide in cell plasma membrane and implications for Alzheimer's disease," Current Protein and Peptide Science, vol. 5, no. 1, pp. 19-31, 2004

[17] T. Wisniewski, J. Ghiso, and B. Frangione, "Biology of $\mathrm{A} \beta$ amyloid in Alzheimer's disease," Neurobiology of Disease, vol. 4, no. 5, pp. 313-328, 1997.

[18] N. J. Haughey, "Sphingolipids in neurodegeneration," NeuroMolecular Medicine, vol. 12, no. 4, pp. 301-305, 2010.

[19] N. J. Haughey, V. V. R. Bandaru, M. Bae, and M. P. Mattson, "Roles for dysfunctional sphingolipid metabolism in Alzheimer's disease neuropathogenesis," Biochimica et Biophysica Acta, vol. 1801, no. 8, pp. 878-886, 2010.

[20] T. Mutoh, Y. Hirabayashi, T. Mihara et al., "Role of glycosphingolipids and therapeutic perspectives on Alzheimer's disease," CNS and Neurological Disorders-Drug Targets, vol. 5, no. 4, pp. 375-380, 2006.

[21] G. P. Gorbenko and P. K. J. Kinnunen, "The role of lipidprotein interactions in amyloid-type protein fibril formation," Chemistry and Physics of Lipids, vol. 141, no. 1-2, pp. 72-82, 2006.

[22] M. O. W. Grimm, J. A. Tschäpe, H. S. Grimm, E. G. Zinser, and T. Hartmann, "Altered membrane fluidity and lipid raft composition in presenilin-deficient cells," Acta Neurologica Scandinavica, vol. 114, no. 185, pp. 27-32, 2006.

[23] P. T. Wong, J. A. Schauerte, K. C. Wisser et al., "Amyloid$\beta$ membrane binding and permeabilization are distinct processes influenced separately by membrane charge and fluidity," Journal of Molecular Biology, vol. 386, no. 1, pp. 8196, 2009.

[24] N. Iwamoto, Y. Suzuki, Y. Makino, C. Haga, K. Kosaka, and R. Iizuka, "Cell membrane changes in brains manifesting senile plaques: an immunohistochemical study of GM membranous ganglioside," Brain Research, vol. 522, no. 1, pp. 152$156,1990$.

[25] H. Takahashi, K. Hirokawa, S. Ando, and K. Obata, "Immunohistological study on brains of Alzheimer's disease using antibodies to fetal antigens, C-series gangliosides and microtubule-associated protein 5," Acta Neuropathologica, vol. 81, no. 6, pp. 626-631, 1991.
[26] T. Nishinaka, D. Iwata, S. Shimada, K. Kosaka, and Y. Suzuki, "Anti-ganglioside GDla monoclonal antibody recognizes senile plaques in the brains of patients with Alzheimer-type dementia," Neuroscience Research, vol. 17, no. 2, pp. 171-176, 1993.

[27] E. Terzi, G. Holzemann, and J. Seelig, "Self-association of $\beta$-amyloid peptide (1-40) in solution and binding to lipid membranes," Journal of Molecular Biology, vol. 252, no. 5, pp. 633-642, 1995.

[28] L. P. Choo-Smith, W. Garzon-Rodriguez, C. G. Glabe, and W. K. Surewicz, "Acceleration of amyloid fibril formation by specific binding of $\mathrm{A} \beta-(1-40)$ peptide to ganglioside-containing membrane vesicles," Journal of Biological Chemistry, vol. 272, no. 37, pp. 22987-22990, 1997.

[29] K. Matsuzaki and C. Horikiri, "Interactions of amyloid $\beta$-peptide (1-40) with ganglioside-containing membranes," Biochemistry, vol. 38, no. 13, pp. 4137-4142, 1999.

[30] J. McLaurin and A. Chakrabartty, "Membrane disruption by Alzheimer $\beta$-amyloid peptides mediated through specific binding to either phospholipids or gangliosides. Implications for neurotoxicity," Journal of Biological Chemistry, vol. 271, no. 43, pp. 26482-26489, 1996.

[31] J. McLaurin, T. Franklin, P. E. Fraser, and A. Chakrabartty, "Structural transitions associated with the interaction of Alzheimer $\beta$-amyloid peptides with gangliosides," Journal of Biological Chemistry, vol. 273, no. 8, pp. 4506-4515, 1998.

[32] L. P. Choo-Smith and W. K. Surewicz, "The interaction between Alzheimer amyloid $\beta(1-40)$ peptide and ganglioside G(M1)-containing membranes," FEBS Letters, vol. 402, no. 2-3, pp. 95-98, 1997.

[33] T. Ariga, K. Kobayashi, A. Hasegawa, M. Kiso, H. Ishida, and T. Miyatake, "Characterization of high-affinity binding between gangliosides and amyloid $\beta$-protein," Archives of Biochemistry and Biophysics, vol. 388, no. 2, pp. 225-230, 2001.

[34] P. K. Mandal and J. W. Pettegrew, “Alzheimer's disease: NMR studies of asialo (GM1) and Trisialo (GT1b) ganglioside interactions with $\mathrm{A} \beta(1-40)$ peptide in a membrane mimic environment," Neurochemical Research, vol. 29, no. 2, pp. 447-453, 2004

[35] Y. Nakazawa, Y. Suzuki, M. P. Williamson, H. Saitô, and T. Asakura, "The interaction of amyloid A $\beta(1-40)$ with lipid bilayers and ganglioside as studied by P solid-state NMR," Chemistry and Physics of Lipids, vol. 158, no. 1, pp. 54-60, 2009.

[36] C. S. Atwood, R. D. Moir, X. Huang et al., "Dramatic aggregation of alzheimer by $\mathrm{Cu}(\mathrm{II})$ is induced by conditions representing physiological acidosis," Journal of Biological Chemistry, vol. 273, no. 21, pp. 12817-12826, 1998.

[37] Y. R. Chen, H. B. Huang, C. L. Chyan, M. S. Shiao, T. H. Lin, and Y. C. Chen, "The effect of $A \beta$ conformation on the metal affinity and aggregation mechanism studied by circular dichroism spectroscopy," Journal of Biochemistry, vol. 139, no. 4, pp. 733-740, 2006.

[38] M. P. Williamson, Y. Suzuki, N. T. Bourne, and T. Asakura, "Binding of amyloid $\beta$-peptide to ganglioside micelles is dependent on histidine-13," Biochemical Journal, vol. 397, no. 3, pp. 483-490, 2006.

[39] H. Zhang, J. Ding, W. Tian et al., "Ganglioside GM1 binding the N-terminus of amyloid precursor protein," Neurobiology of Aging, vol. 30, no. 8, pp. 1245-1253, 2009.

[40] M. Utsumi, Y. Yamaguchi, H. Sasakawa, N. Yamamoto, K. Yanagisawa, and K. Kato, "Up-and-down topological mode 
of amyloid $\beta$-peptide lying on hydrophilic/hydrophobic interface of ganglioside clusters," Glycoconjugate Journal, vol. 26, no. 8, pp. 999-1006, 2009.

[41] M. Yagi-Utsumi, T. Kameda, Y. Yamaguchi, and K. Kato, "NMR characterization of the interactions between lysoGM1 aqueous micelles and amyloid $\beta$," FEBS Letters, vol. 584, no. 4, pp. 831-836, 2010.

[42] K. Yanagisawa, A. Odaka, N. Suzuki, and Y. Ihara, "GM1 ganglioside-bound amyloid $\beta$-protein $(\mathrm{AB})$ : a possible form of preamyloid in Alzheimer's disease," Nature Medicine, vol. 1, no. 10, pp. 1062-1066, 1995.

[43] K. Yanagisawa, "Role of gangliosides in Alzheimer's disease," Biochimica et Biophysica Acta, vol. 1768, no. 8, pp. 1943-1951, 2007.

[44] K. Yanagisawa and Y. Ihara, "GM1 ganglioside-bound amyloid $\beta$-protein in Alzheimer's disease brain," Neurobiology of Aging, vol. 19, no. 1, pp. S65-S67, 1998.

[45] N. Kimura and K. Yanagisawa, "Endosomal accumulation of GM1 ganglioside-bound amyloid $\beta$-protein in neurons of aged monkey brains," NeuroReport, vol. 18, no. 16, pp. 1669 $1673,2007$.

[46] B. Kurganov, M. Doh, and N. Arispe, "Aggregation of liposomes induced by the toxic peptides Alzheimer's A $\beta$ s, human amylin and prion (106-126): facilitation by membranebound GM1 ganglioside," Peptides, vol. 25, no. 2, pp. 217232, 2004.

[47] N. Yamamoto, Y. Hirabayashi, M. Amari et al., "Assembly of hereditary amyloid $\beta$-protein variants in the presence of favorable gangliosides," FEBS Letters, vol. 579, no. 10, pp. 2185-2190, 2005.

[48] T. Okada, K. Ikeda, M. Wakabayashi, M. Ogawa, and K. Matsuzaki, "Formation of toxic A $\beta(1-40)$ fibrils on GM1 ganglioside-containing membranes mimicking lipid rafts: polymorphisms in A $\beta(1-40)$ fibrils," Journal of Molecular Biology, vol. 382, no. 4, pp. 1066-1074, 2008.

[49] K. Yanagisawa, "Cholesterol and A $\beta$ aggregation," Pharmacopsychiatry, vol. 36, no. 2, pp. S127-S129, 2003.

[50] K. Yanagisawa and K. Matsuzaki, "Cholesterol-dependent aggregation of amyloid $\beta$-protein," Annals of the New York Academy of Sciences, vol. 977, pp. 384-386, 2002.

[51] M. Wakabayashi and K. Matsuzaki, "Formation of amyloids by $\mathrm{A} \beta-(1-42)$ on NGF-differentiated PC12 cells: roles of gangliosides and cholesterol," Journal of Molecular Biology, vol. 371, no. 4, pp. 924-933, 2007.

[52] S. S. S. Wang, D. L. Rymer, and T. A. Good, "Reduction in cholesterol and sialic acid content protects cells from the toxic effects of $\beta$-amyloid peptides," Journal of Biological Chemistry, vol. 276, no. 45, pp. 42027-42034, 2001.

[53] M. S. Lin, L. Y. Chen, S. S. S. Wang, Y. Chang, and W. Y. Chen, "Examining the levels of ganglioside and cholesterol in cell membrane on attenuation the cytotoxicity of beta-amyloid peptide," Colloids and Surfaces B, vol. 65, no. 2, pp. 172-177, 2008.

[54] Q. Zha, Y. Ruan, T. Hartmann, K. Beyreuther, and D. Zhang, "GM1 ganglioside regulates the proteolysis of amyloid precursor protein," Molecular Psychiatry, vol. 9, no. 10, pp. 946952, 2004.

[55] H. Hayashi, N. Kimura, H. Yamaguchi et al., "A seed for Alzheimer amyloid in the brain," Journal of Neuroscience, vol. 24, no. 20, pp. 4894-4902, 2004.

[56] K. Yuyama and K. Yanagisawa, "Late endocytic dysfunction as a putative cause of amyloid fibril formation in Alzheimer's disease," Journal of Neurochemistry, vol. 109, no. 5, pp. 12501260, 2009.
[57] N. Yamamoto, T. Matsubara, T. Sato, and K. Yanagisawa, "Age-dependent high-density clustering of GM1 ganglioside at presynaptic neuritic terminals promotes amyloid $\beta$ protein fibrillogenesis," Biochimica et Biophysica Acta, vol. 1778, no. 12, pp. 2717-2726, 2008.

[58] N. Yamamoto, T. Yokoseki, M. Shibata, H. Yamaguchi, and K. Yanagisawa, "Suppression of $A \beta$ deposition in brain by peripheral administration of Fab fragments of anti-seed antibody," Biochemical and Biophysical Research Communications, vol. 335, no. 1, pp. 45-47, 2005.

[59] K. Yuyama and K. Yanagisawa, "Sphingomyelin accumulation provides a favorable milieu for GM1 gangliosideinduced assembly of amyloid $\beta$-protein," Neuroscience Letters, vol. 481, no. 3, pp. 168-172, 2010.

[60] K. Yanagisawa, "GM1 ganglioside and the seeding of amyloid in Alzheimer's disease: endogenous seed for Alzheimer amyloid," Neuroscientist, vol. 11, no. 3, pp. 250-260, 2005.

[61] J. Fantini, N. Garmy, R. Mahfoud, and N. Yahi, "Lipid rafts: structure, function and role in HIV, Alzheimer's and prion diseases," Expert Reviews in Molecular Medicine, vol. 4, no. 27, pp. 1-22, 2002.

[62] A. Kakio, S. I. Nishimoto, K. Yanagisawa, Y. Kozutsumi, and K. Matsuzaki, "Interactions of amyloid $\beta$-protein with various gangliosides in raft-like membranes: importance of GM1 ganglioside-bound form as an endogenous seed for Alzheimer amyloid," Biochemistry, vol. 41, no. 23, pp. 73857390, 2002.

[63] Y. Mao, Z. Shang, Y. Imai et al., "Surface-induced phase separation of a sphingomyelin/cholesterol/ganglioside GM1planar bilayer on mica surfaces and microdomain molecular conformation that accelerates A $\beta$ oligomerization," Biochimica et Biophysica Acta, vol. 1798, no. 6, pp. 1090-1099, 2010.

[64] K. Matsuzaki, K. Kato, and K. Yanagisawa, "A $\beta$ polymerization through interaction with membrane gangliosides," Biochimica et Biophysica Acta, vol. 1801, no. 8, pp. 868-877, 2010.

[65] K. Matsuzaki, "Interactions between amyloid beta-protein and gangliosides," Tanpakushitsu Kakusan Koso, vol. 47, no. 4, pp. 351-356, 2002.

[66] S. I. Kim, J. S. Yi, and Y. G. Ko, "Amyloid $\beta$ oligomerization is induced by brain lipid rafts," Journal of Cellular Biochemistry, vol. 99, no. 3, pp. 878-889, 2006.

[67] M. Wakabayashi and K. Matsuzaki, "Ganglioside-induced amyloid formation by human islet amyloid polypeptide in lipid rafts," FEBS Letters, vol. 583, no. 17, pp. 2854-2858, 2009.

[68] N. Yamamoto, E. Matsubara, S. Maeda et al., "A gangliosideinduced toxic soluble $\mathrm{A} \beta$ assembly: its enhanced formation from $\mathrm{A} \beta$ bearing the arctic mutation," Journal of Biological Chemistry, vol. 282, no. 4, pp. 2646-2655, 2007.

[69] N. Yamamoto, Y. Hirabayashi, M. Amari et al., "Assembly of hereditary amyloid $\beta$-protein variants in the presence of favorable gangliosides," FEBS Letters, vol. 579, no. 10, pp. 2185-2190, 2005.

[70] N. Yamamoto, W. E. Van Nostrand, and K. Yanagisawa, "Further evidence of local ganglioside-dependent amyloid $\beta$ protein assembly in brain," NeuroReport, vol. 17, no. 16, pp. 1735-1737, 2006.

[71] M. Wakabayashi, T. Okada, Y. Kozutsumi, and K. Matsuzaki, "GM1 ganglioside-mediated accumulation of amyloid $\beta$ protein on cell membranes," Biochemical and Biophysical Research Communications, vol. 328, no. 4, pp. 1019-1023, 2005. 
[72] M. Yanagisawa, T. Ariga, and R. K. Yu, "Fucosyl-GM1 expression and amyloid- $\beta$ protein accumulation in PC12 cells," Journal of Neuroscience Research, vol. 84, no. 6, pp. 13431349, 2006.

[73] T. Ariga, K. Kobayashi, Y. Kuroda et al., "Characterization of tumor-associated fucogangliosides from PC 12 pheochromocytoma cells," Journal of Biological Chemistry, vol. 262, no. 29, pp. 14146-14153, 1987.

[74] Y. Yamazaki, Y. Horibata, Y. Magatsuka, Y. Hirabayashi, and T. Hashikawa, "Fucoganglioside $\alpha$-fucosyl ( $\alpha$-galactosyl)GM1: a novel member of lipid membrane microdomain components involved in PC12 cell neuritogenesis," Biochemical Journal, vol. 407, no. 1, pp. 31-40, 2007.

[75] T. Ariga, L. J. Macala, M. Saito et al., "Lipid composition of PC12 pheochromocytoma cells: characterization of globoside as a major neutral glycolipid," Biochemistry, vol. 27, no. 1, pp. 52-58, 1988.

[76] M. Molander-Melin, K. Blennow, N. Bogdanovic, B. Dellheden, J. E. Månsson, and P. Fredman, "Structural membrane alterations in Alzheimer brains found to be associated with regional disease development; increased density of gangliosides GM1 and GM2 and loss of cholesterol in detergentresistant membrane domains," Journal of Neurochemistry, vol. 92, no. 1, pp. 171-182, 2005.

[77] G. P. Eckert, W. G. Wood, and W. E. Müller, "Lipid membranes and $\beta$-amyloid: a harmful connection," Current Protein and Peptide Science, vol. 11, no. 5, pp. 319-325, 2010.

[78] S. Kalanj, I. Kracun, H. Rosner, and C. Cosović, "Regional distribution of brain gangliosides in Alzheimer's disease," Neurologia Croatica, vol. 40, no. 4, pp. 269-281, 1991.

[79] S. Kalanj-Bognar, "Ganglioside catabolism is altered in fibroblasts and leukocytes from Alzheimer's disease patients," Neurobiology of Aging, vol. 27, no. 9, pp. 1354-1356, 2006.

[80] L. Svennerholm and C. G. Gottfries, "Membrane lipids, selectively diminished in Alzheimer brains, suggest synapse loss as a primary event in early-onset form (type I) and demyelination in late-onset form (type II)," Journal of Neurochemistry, vol. 62, no. 3, pp. 1039-1047, 1994.

[81] I. Kracun, S. Kalanj, C. Cosovic, and J. Talan-Hranilovic, "Brain gangliosides in Alzheimer's disease," Journal für Hirnforschung, vol. 31, no. 6, pp. 789-793, 1990.

[82] I. Kracun, S. Kalanj, J. Talan-Hranilovic, and C. Cosovic, "Cortical distribution of gangliosides in Alzheimer's disease," Neurochemistry International, vol. 20, no. 3, pp. 433-438, 1992.

[83] B. W. L. Brooksbank and J. McGovern, "Gangliosides in the brain in adult Down's syndrome and Alzheimer's disease," Molecular and Chemical Neuropathology, vol. 11, no. 3, pp. 143-156, 1989.

[84] P. B. Crino, M. D. Ullman, B. A. Vogt, E. D. Bird, and L. Volicer, "Brain gangliosides in dementia of the Alzheimer type," Archives of Neurology, vol. 46, no. 4, pp. 398-401, 1989.

[85] T. Ariga, M. Yanagisawa, C. Wakade et al., "Ganglioside metabolism in a transgenic mouse model of alzheimer's disease: expression of Chol- $1 \alpha$ antigens in the brain," ASN Neuro, vol. 2, no. 4, pp. 233-241, 2010.

[86] N. Sawamura, M. Morishima-Kawashima, H. Waki et al., "Mutant presenilin 2 transgenic mice: a large increase in the levels of $A \beta 342$ is presumably associated with the low density membrane domain that contains decreased levels of glycerophospholipids and sphingomyelin," Journal of Biological Chemistry, vol. 275, no. 36, pp. 27901-27908, 2000.

[87] A. Bernardo, F. E. Harrison, M. McCord et al., "Elimination of GD3 synthase improves memory and reduces amyloid- $\beta$ plaque load in transgenic mice," Neurobiology of Aging, vol. 30, no. 11, pp. 1777-1791, 2009.

[88] L. Barrier, S. Ingrand, M. Damjanac, A. Rioux Bilan, J. Hugon, and G. Page, "Genotype-related changes of ganglioside composition in brain regions of transgenic mouse models of Alzheimer's disease," Neurobiology of Aging, vol. 28, no. 12, pp. 1863-1872, 2007.

[89] S. Ando, Y. Hirabayashi, K. Kon, F. Inagaki, S. Tate, and V. P. Whittaker, "A trisialoganglioside containing a sialyl $\alpha 2-6 \mathrm{~N}$ acetylgalactosamine residue is a cholinergic-specific antigen, Chol-1 $\alpha$," Journal of Biochemistry, vol. 111, no. 3, pp. 287290, 1992.

[90] Y. Hirabayashi, T. Nakao, F. Irie, V. P. Whittaker, K. Kon, and S. Ando, "Structural characterization of a novel cholinergic neuron-specific ganglioside in bovine brain," Journal of Biological Chemistry, vol. 267, no. 18, pp. 12973-12978, 1992.

[91] E. A. Derrington and E. Borroni, "The developmental expression of the cholinergic-specific antigen Chol-1 in the central and peripheral nervous system of the rat," Developmental Brain Research, vol. 52, no. 1-2, pp. 131-140, 1990.

[92] S. Ando, Y. Tanaka, S. Kobayashi et al., "Synaptic function of cholinergic-specific Chol-1 $\alpha$ ganglioside," Neurochemical Research, vol. 29, no. 4, pp. 857-867, 2004.

[93] S. Ando, Y. Tanaka, H. Waki, K. Kon, M. Iwamoto, and F. Fukui, "Gangliosides and sialylcholesterol as modulators of synaptic functions," Annals of the New York Academy of Sciences, vol. 845, pp. 232-239, 1998.

[94] J. Chapman, O. Bachar, A. D. Korczyn, E. Wertman, and D. M. Michaelson, "Antibodies to cholinergic neurons in Alzheimer's disease," Journal of Neurochemistry, vol. 51, no. 2, pp. 479-485, 1988.

[95] N. F. Ho, S. Han, and G. S. Dawe, "Effect of voluntary running on adult hippocampal neurogenesis in cholinergic lesioned mice," BMC Neuroscience, vol. 10, article 57, 2009.

[96] D. A. Greenberg and K. Jin, "Neurodegeneration and neurogenesis: focus on Alzheimer's disease," Current Alzheimer Research, vol. 3, no. 1, pp. 25-28, 2006.

[97] K. Jin, V. Galvan, L. Xie et al., "Enhanced neurogenesis in Alzheimer's disease transgenic (PDGF-APP ) mice," Proceedings of the National Academy of Sciences of the United States of America, vol. 101, no. 36, pp. 13363-13367, 2004.

[98] M. A. Lopez-Toledano, M. A. Faghihi, N. S. Patel, and C. Wahlestedt, "Adult neurogenesis: a potential tool for early diagnosis in alzheimer's disease?" Journal of Alzheimer's Disease, vol. 20, no. 2, pp. 395-408, 2010.

[99] M. A. López-Toledano and M. L. Shelanski, "Increased neurogenesis in young transgenic mice overexpressing human APP(Sw, Ind)," Journal of Alzheimer's Disease, vol. 12, no. 3, pp. 229-240, 2007.

[100] N. Oikawa, H. Yamaguchi, K. Ogino et al., "Gangliosides determine the amyloid pathology of Alzheimer's disease," NeuroReport, vol. 20, no. 12, pp. 1043-1046, 2009.

[101] M. Okada, M.-I. Itoh, M. Haraguchi et al., "b-series Ganglioside deficiency exhibits no definite changes in the neurogenesis and the sensitivity to Fas-mediated apoptosis but impairs regeneration of the lesioned hypoglossal nerve," Journal of Biological Chemistry, vol. 277, no. 3, pp. 16331636, 2002.

[102] G. C. Gregory, V. Macdonald, P. R. Schofield, J. J. Kril, and G. M. Halliday, "Differences in regional brain atrophy in genetic forms of Alzheimer's disease," Neurobiology of Aging, vol. 27, no. 3, pp. 387-393, 2006. 
[103] L. Crews and E. Masliah, "Molecular mechanisms of neurodegeneration in Alzheimer's disease," Human Molecular Genetics, vol. 19, no. 1, pp. R12-R20, 2010.

[104] P. Taupin, "Therapeutic potential of adult neural stem cells," Recent Patents on CNS Drug Discovery, vol. 1, no. 3, pp. 299303, 2006.

[105] A. Shruster, E. Melamed, and D. Offen, "Neurogenesis in the aged and neurodegenerative brain," Apoptosis, vol. 15, no. 11, pp. 1415-1421, 2010.

[106] L. Crews, E. Rockenstein, and E. Masliah, "APP transgenic modeling of Alzheimer's disease: mechanisms of neurodegeneration and aberrant neurogenesis," Brain Structure and Function, vol. 214, no. 2-3, pp. 111-126, 2010.

[107] K. Boekhoorn, M. Joels, and P. J. Lucassen, "Increased proliferation reflects glial and vascular-associated changes, but not neurogenesis in the presenile Alzheimer hippocampus," Neurobiology of Disease, vol. 24, no. 1, pp. 1-14, 2006.

[108] M. H. Donovan, U. Yazdani, R. D. Norris, D. Games, D. C. German, and A. J. Eisch, "Decreased adult hippocampal neurogenesis in the PDAPP mouse model of Alzheimer's disease," Journal of Comparative Neurology, vol. 495, no. 1, pp. 70-83, 2006.

[109] N. J. Haughey, D. Liu, A. Nath, A. C. Borchard, and M. P. Mattson, "Disruption of neurogenesis in the subventricular zone of adult mice, and in human cortical neuronal precursor cells in culture, by amyloid $\beta$-peptide: implications for the pathogenesis of Alzheimer's disease," NeuroMolecular Medicine, vol. 1, no. 2, pp. 125-135, 2002.

[110] N. J. Haughey, A. Nath, S. L. Chan, A. C. Borchard, M. S. Rao, and M. P. Mattson, "Disruption of neurogenesis by amyloid $\beta$-peptide, and perturbed neural progenitor cell homeostasis, in models of Alzheimer's disease," Journal of Neurochemistry, vol. 83, no. 6, pp. 1509-1524, 2002.

[111] F. V. Ermini, S. Grathwohl, R. Radde et al., "Neurogenesis and alterations of neural stem cells in mouse models of cerebral amyloidosis," American Journal of Pathology, vol. 172, no. 6, pp. 1520-1528, 2008.

[112] C. Zhang, E. McNeil, L. Dressler, and R. Siman, "Long-lasting impairment in hippocampal neurogenesis associated with amyloid deposition in a knock-in mouse model of familial Alzheimer's disease," Experimental Neurology, vol. 204, no. 1, pp. 77-87, 2007.

[113] M. Yanagisawa and R. K. Yu, "O-linked $\beta$-N-acetylglucosaminylation in mouse embryonic neural precursor cells," Journal of Neuroscience Research, vol. 87, no. 16, pp. 35353545, 2009.

[114] M. Yanagisawa, K. Nakamura, and T. Taga, "Glycosphingolipid synthesis inhibitor represses cytokine-induced activation of the Ras-MAPK pathway in embryonic neural precursor cells," Journal of Biochemistry, vol. 138, no. 3, pp. 285-291, 2005.

[115] Y. Chen and C. Dong, "A $\beta 40$ promotes neuronal cell fate in neural progenitor cells," Cell Death and Differentiation, vol. 16, no. 3, pp. 386-394, 2009.

[116] A. R. Koudinov and T. T. Berezov, "Alzheimer's amyloid-beta $(\mathrm{A} \beta)$ is an essential synaptic protein, not neurotoxic junk," Acta Neurobiologiae Experimentalis, vol. 64, no. 1, pp. 71-79, 2004.

[117] M. A. López-Toledano and M. L. Shelanski, "Neurogenic effect of $\beta$-amyloid peptide in the development of neural stem cells," Journal of Neuroscience, vol. 24, no. 23, pp. 54395444, 2004.

[118] M. Calafiore, G. Battaglia, A. Zappalà et al., "Progenitor cells from the adult mouse brain acquire a neuronal phenotype in response to $\beta$-amyloid," Neurobiology of Aging, vol. 27, no. 4, pp. 606-613, 2006.

[119] A. Sotthibundhu, Q.-X. Li, W. Thangnipon, and E. J. Coulson, "A $\beta 1-42$ stimulates adult SVZ neurogenesis through the p75 neurotrophin receptor," Neurobiology of Aging, vol. 30, no. 12, pp. 1975-1985, 2009.

[120] C. Malaplate-Armand, S. Florent-Béchard, I. Youssef et al., "Soluble oligomers of amyloid- $\beta$ peptide induce neuronal apoptosis by activating a cPLA2-dependent sphingomyelinase-ceramide pathway," Neurobiology of Disease, vol. 23, no. 1, pp. 178-189, 2006.

[121] A. Sotthibundhu, A. M. Sykes, B. Fox, C. K. Underwood, W. Thangnipon, and E. J. Coulson, " $\beta$-amyloid1-42 induces neuronal death through the p75 neurotrophin receptor," Journal of Neuroscience, vol. 28, no. 15, pp. 3941-3946, 2008.

[122] S. I. Hayashi, N. Sato, A. Yamamoto et al., "Alzheimer disease-associated peptide, amyloid $\beta 40$, inhibits vascular regeneration with induction of endothelial autophagy," Arteriosclerosis, Thrombosis, and Vascular Biology, vol. 29, no. 11, pp. 1909-1915, 2009.

[123] Y. Gong, L. Chang, K. L. Viola et al., "Alzheimer's diseaseaffected brain: presence of oligomeric $\mathrm{A} \beta$ ligands (ADDLs) suggests a molecular basis for reversible memory loss," Proceedings of the National Academy of Sciences of the United States of America, vol. 100, no. 18, pp. 10417-10422, 2003.

[124] C. Heo, K.-A. Chang, H. S. Choi et al., "Effects of the monomeric, oligomeric, and fibrillar A $\beta 42$ peptides on the proliferation and differentiation of adult neural stem cells from subventricular zone," Journal of Neurochemistry, vol. 102, no. 2, pp. 493-500, 2007.

[125] J. T. Lee, J. Xu, J. M. Lee et al., "Amyloid- $\beta$ peptide induces oligodendrocyte death by activating the neutral sphingomyelinase-ceramide pathway," Journal of Cell Biology, vol. 164, no. 1, pp. 123-131, 2004.

[126] P. Millet, C. Silva Lages, S. Haïk et al., "Amyloid- $\beta$ peptide triggers Fas-independent apoptosis and differentiation of neural progenitor cells," Neurobiology of Disease, vol. 19, no. 1-2, pp. 57-65, 2005.

[127] X. Li and P. Zuo, "Effects of A $\beta$ on neurogenesis in the adult mouse subventricular zone and dentate gyrus," Neurological Research, vol. 27, no. 2, pp. 218-222, 2005.

[128] E. Cazzaniga, A. Bulbarelli, A. Cassetti et al., " $\beta$-amyloid (2535) enhances lipid metabolism and protein ubiquitination in cultured neurons," Journal of Neuroscience Research, vol. 85, no. 10, pp. 2253-2261, 2007.

[129] A. Copani, D. Melchiorri, A. Caricasole et al., “ $\beta$-amyloidinduced synthesis of the ganglioside GD3 is a requisite for cell cycle reactivation and apoptosis in neurons," Journal of Neuroscience, vol. 22, no. 10, pp. 3963-3968, 2002.

[130] M. Yanagisawa, T. Ariga, and R. K. Yu, "Cytotoxic effects of GM1 ganglioside and amyloid $\beta$-peptide on mouse embryonic neural stem cells," ASN Neuro, vol. 2, no. 1, pp. 49-56, 2010.

[131] D. L. Hynds, R. W. Burry, and A. J. Yates, "Gangliosides inhibit growth factor-stimulated neurite outgrowth in SHSY5Y human neuroblastoma cells," Journal of Neuroscience Research, vol. 47, no. 6, pp. 617-625, 1997.

[132] A. Leon, D. Benvegnu, and R. Dal Toso, "Dorsal root ganglia and nerve growth factor: a model for understanding the mechanism of GM1 effects on neuronal repair," Journal of Neuroscience Research, vol. 12, no. 2-3, pp. 277-287, 1984.

[133] H. Dreyfus, B. Ferret, S. Harth, A. Gorio, L. Freysz, and R. Massarelli, "Effect of exogenous gangliosides on the morphology and biochemistry of cultured neurons," Advances in 
Experimental Medicine and Biology, vol. 174, pp. 513-524, 1984.

[134] S. Tsuji, T. Yamashita, and Y. Nagai, "A novel, carbohydrate signal-mediated cell surface protein phosphorylation: ganglioside GQ1b stimulates ecto-protein kinase activity on the cell surface of a human neuroblastoma cell line, GOTO," Journal of Biochemistry, vol. 104, no. 4, pp. 498-503, 1988.

[135] J. L. Jankowsky, H. H. Slunt, T. Ratovitski, N. A. Jenkins, N. G. Copeland, and D. R. Borchelt, "Co-expression of multiple transgenes in mouse CNS: a comparison of strategies," Biomolecular Engineering, vol. 17, no. 6, pp. 157-165, 2001.

[136] L. Wu, A. A. Sluiter, H. F. Guo et al., "Neural stem cells improve neuronal survival in cultured postmortem brain tissue from aged and Alzheimer patients," Journal of Cellular and Molecular Medicine, vol. 12, no. 5A, pp. 1611-1621, 2008.

[137] K. Matsuzaki, T. Noguch, M. Wakabayashi et al., "Inhibitors of amyloid $\beta$-protein aggregation mediated by GM1containing raft-like membranes," Biochimica et Biophysica Acta, vol. 1768, no. 1, pp. 122-130, 2007.

[138] L. Svennerholm, “The gangliosides," Journal of Lipid Research, vol. 5, no. 4, pp. 145-126, 1964. 


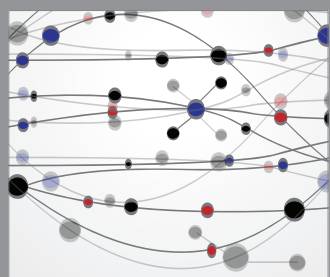

The Scientific World Journal
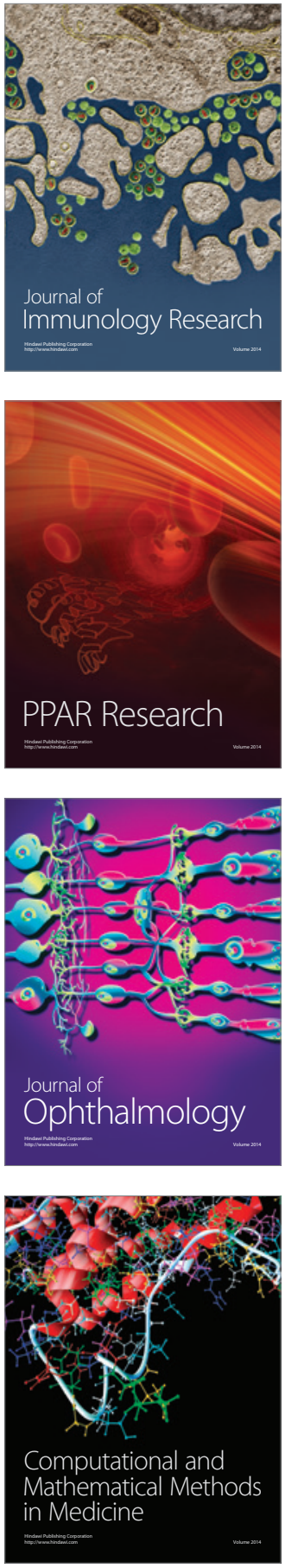

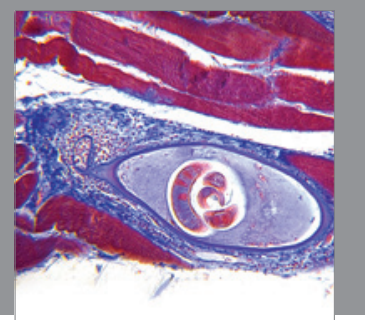

Gastroenterology

Research and Practice
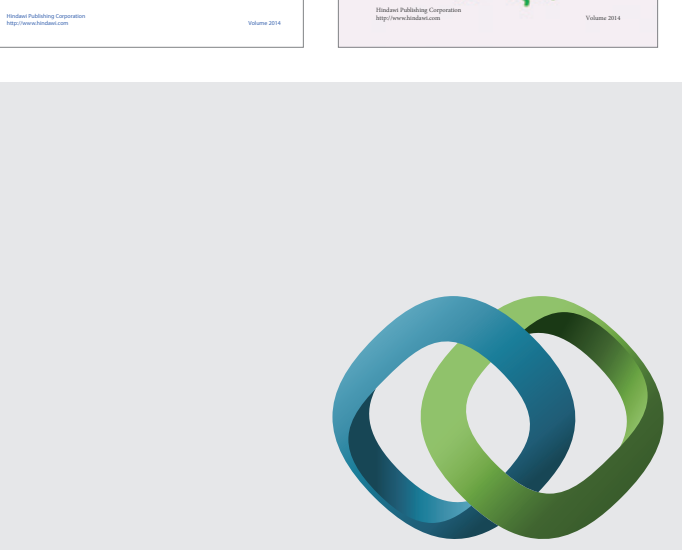

\section{Hindawi}

Submit your manuscripts at

http://www.hindawi.com
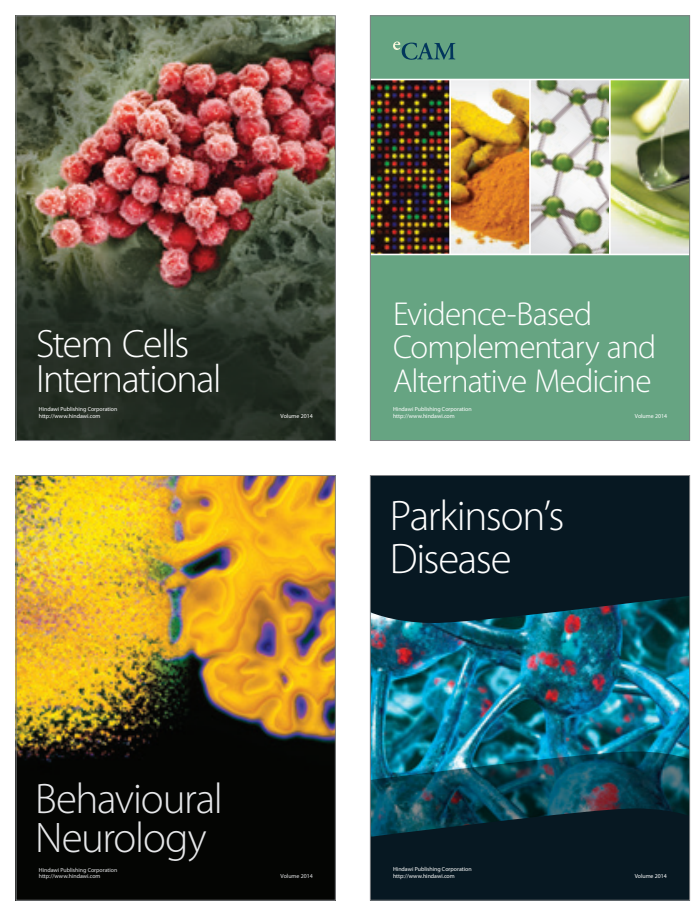

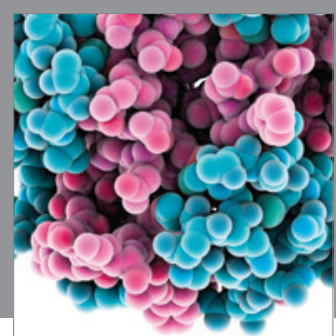

Journal of
Diabetes Research

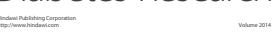

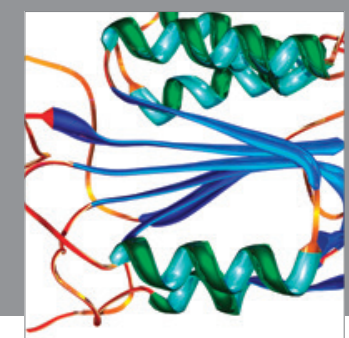

Disease Markers
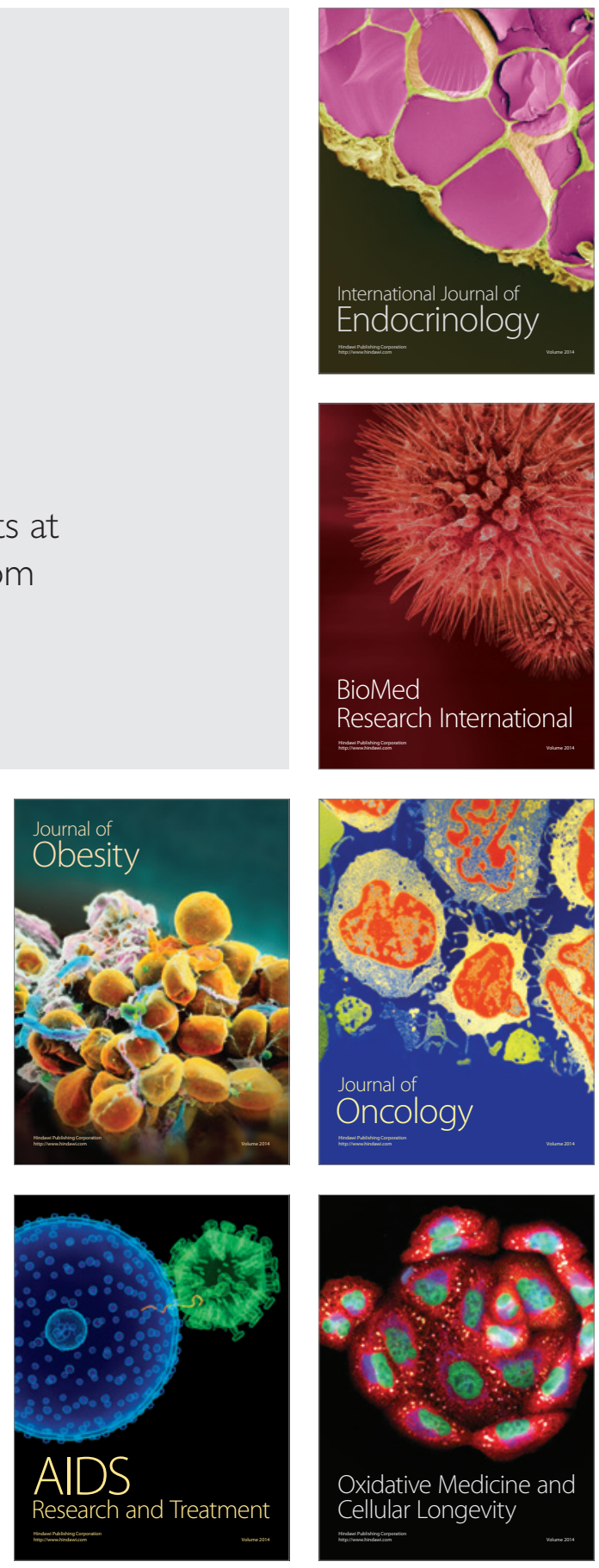